\title{
Growth hormone stimulates adipogenesis of 3T3-L1 cells through activation of the Stat5A/5B-PPAR $\gamma$ pathway
}

\author{
Masanobu Kawai, Noriyuki Namba, Sotaro Mushiake, Yuri Etani, Riko Nishimura1, \\ Makoto Makishima ${ }^{2}$ and Keiichi Ozono \\ Department of Pediatrics, Osaka University Graduate School of Medicine, 2-2 Yamadaoka, Suita, Osaka 565-0871, Japan \\ ${ }^{1}$ Department of Biochemistry, Graduate School of Dentistry, Osaka University, 1-8 Yamadaoka, Suita, Osaka 565-0871, Japan \\ ${ }^{2}$ Department of Biochemistry, Nihon University School of Medicine, 30-1 Oyaguchi-kamicho, Itabashi-ku, Tokyo 173-8610, Japan \\ (Requests for offprints should be addressed to K Ozono; Email: keioz@ped.med.osaka-u.ac.jp)
}

\begin{abstract}
Growth hormone-deficient (GHD) patients show a decreased number of adipocytes, which is normalized by GH replacement, indicating an adipogenic effect of $\mathrm{GH}$. However, the precise mechanisms underlying this effect remain to be clarified. In this study, we investigated the adipogenic effect of GH. GH stimulated MDI (3-isobutyl-1-methylxanthine, dexamethasone, and insulin)-induced adipogenesis of 3T3-L1 cells with early induction of peroxisome proliferator-activated receptors (PPAR) $\gamma 2$ expression. This adipogenic effect of $\mathrm{GH}$ was suppressed by overexpression of Stat5A mutant (Stat5A-Y694F), a transcriptional suppressor for the $\mathrm{GH}-\mathrm{Stat} 5 \mathrm{~A} / 5 \mathrm{~B}$ signaling pathway, with the reduction of PPAR $\gamma 2$ expression. Next, we investigated the relationship between Stat5A/5B and CCAAT/enhancer binding protein (C/EBP) $\beta / \delta$ or PPAR $\gamma$ in $3 T 3-L 1$ cells. Stat5A/5B stimulated C/EBP $\beta$ - and C/EBP $\delta$-induced adipogenesis with enhancement of PPAR $\gamma 2$ expression. In addition, Stat5A/5B enhanced the transcriptional activity of $C / E B P \beta / \delta$ in the PPAR $\gamma$ gene promoter. Furthermore, Stat5A/5B stimulated PPAR $\gamma$-induced adipogenesis and enhanced the transcriptional activity of PPAR $\gamma$. These results suggest that the $\mathrm{GH}-\mathrm{Stat} 5 \mathrm{~A} / 5 \mathrm{~B}$ signaling pathway stimulates adipogenesis in cooperation with C/EBP $\beta / \delta$ and PPAR $\gamma$. To completely understand the effect of $\mathrm{GH}, \mathrm{cDNA}$ microarray analysis was performed to screen genes affected by GH during MDI-induced adipogenesis. Among 4277 genes, 18 and 19 genes were up- and down-regulated respectively. cDNA microarray analysis also indicated the up-regulation of PPAR $\gamma$ and the modulation of expression of genes coding for growth factors or growth factor receptors, suggesting that $\mathrm{GH}$ stimulates adipogenesis in association with the modulation of cell growth. Thus, the GHStat5A/B signaling pathway stimulates adipogenesis through two distinct steps. In addition, cDNA microarray data provide us the further insights underlying the adipogenic effect of $\mathrm{GH}$.
\end{abstract}

Journal of Molecular Endocrinology (2007) 38, 19-34

\section{Introduction}

Growth hormone $(\mathrm{GH})$ is not only a major regulator of postnatal somatic growth, but also has an important role in the control of body composition and fat distribution, through the combination of anabolic, lipolytic, and anti-natriuretic actions (Isaksson et al. 1982, Nam \& Lobie 2000, Tollet-Egnell et al. 2004, Rowland et al. 2005). Indeed, GH-deficient (GHD) patients exhibit a decreased number of adipocytes and an increased mean volume of adipocytes, and this abnormal adipose tissue composition is normalized by GH replacement (Bonnet et al. 1974, Salomon et al. 1989, Bengtsson et al. 1993). As GH replacement increases the number of adipocytes in GHD patients, this indicates a stimulatory effect of $\mathrm{GH}$ on adipogenesis. To date, adipogenic activity of $\mathrm{GH}$ has been reported in studies in vitro (Morikawa et al. 1984, Nixon \& Green 1984). GH is strictly required in the conversion of preadipocytes to adipocytes and is thought to play a role in priming the cells to become responsive to insulin and insulin-like growth factor-I (IGF-I) in 3T3F442A cells (Guller et al. 1989, Corin et al. 1990, Wabitsch et al. 1995). In other cell lines, GH also stimulates adipogenesis, although the role of GH is not exclusive (Doglio et al. 1986, Tominaga et al. 2002). However, little is known about the precise mechanisms of the stimulatory effect of $\mathrm{GH}$ on adipogenesis.

Adipogenesis is a well-regulated process controlled by the sequential activation of various transcription factors (Rosen \& Spiegelman 2000). Adipogenic hormones, including insulin, glucocorticoids, and cAMP-producing factors, and fetal calf serum (FCS) allow growth-arrested preadipocytes to re-enter the cell cycle and undergo approximately two rounds of mitosis called mitotic clonal expansion. Both CCAAT/enhancer-binding protein $(\mathrm{C} / \mathrm{EBP}) \beta$ and $\mathrm{C} / \mathrm{EBP} \delta$ are transiently induced during this period. These transcription factors induce the expression of peroxisome proliferator-activated receptor $(\mathrm{PPAR}) \gamma$. PPAR $\gamma$ in turn stimulates the expression of 
$\mathrm{C} / \mathrm{EBP} \alpha$. Subsequently, PPAR $\gamma$ and $\mathrm{C} / \mathrm{EBP} \alpha$ positively activate the transcription of each other. Concurrently, adipogenesis enters the terminal differentiation stage, and adipocyte-specific genes including aP2, leptin, and adiponectin begin to be expressed. Although $\mathrm{C} / \mathrm{EBP} \beta$ and $\mathrm{C} / \mathrm{EBP} \delta$ have an important role in adipogenesis, mice lacking both $\mathrm{C} / \mathrm{EBP} \beta$ and $\mathrm{C} / \mathrm{EBP} \delta$ exhibited normal PPAR $\gamma$ expression in adipose tissue, indicating that PPAR $\gamma$ expression is maintained through several pathways (Tanaka et al. 1997). In addition, PPAR $\gamma$ null cells showed no adipogenic potential (Rosen et al. 1999). Combined together, $\mathrm{PPAR} \gamma$ rather than $\mathrm{C} / \mathrm{EBP} \beta / \delta$ has the essential role in adipogenesis.

Signal transducer and activator of transcription Stat5A and 5B, both of which have an approximately 90\% identical sequence at amino acid levels, are key transducers of the GH signaling pathway (Darnell 1997). When GH binds to GH receptor (GHR), cytoplasmic tyrosine kinase Janus kinase 2 (JAK2) associates with the cytoplasmic domain of GHR and phosphorylates Stat5A/5B. Phosphorylated Stat5A/5B dimerizes, translocates into the nucleus and binds to the DNA (Piwien-Pilipuk et al. 2002). Stat5A/ 5B-deficient mice showed reduced weight, similar to GH- or GHR-deficient mice, and had approximately one-fifth the epidermal fat pad of wild-type mice, indicating that GH may exert its effect on adipose tissue formation through Stat5A/5B (Teglund et al. 1998). Consistent with this, several investigators have reported the contribution of Stat5A to adipogenesis in some cell lines (Yarwood et al. 1999, Nanbu-Wakao et al. 2002, Floyd \& Stephens 2003, Shang \& Waters 2003, Stewart et al. 2004). However, the precise mechanisms by which Stat5A promotes adipogenesis have not been completely established. Furthermore, the role of Stat5B in adipogenesis remains to be clarified.

In addition to transcription factors and signaling transducers known to be involved in adipogenesis, it is necessary to examine the expression pattern of a number of genes to completely understand the effect of GH on adipogenesis. To achieve this purpose, we performed cDNA microarray analysis to screen the gene profiles during the course of GH-mediated adipogenesis of 3T3-L1 cells.

In this study, we attempted to elucidate the role of Stat5A and 5B in the stimulatory effect of $\mathrm{GH}$ on adipogenesis, and demonstrated that $\mathrm{GH}$ exerts its effect through Stat5A and 5B, which stimulates PPAR $\gamma$ expression. Furthermore, we revealed that Stat5A and $5 \mathrm{~B}$ enhance $\mathrm{C} / \mathrm{EBP} \beta-, \mathrm{C} / \mathrm{EBP} \delta$-, and PPAR $\gamma$-induced adipogenesis. Interestingly, Stat5A and $5 \mathrm{~B}$ enhanced the transcriptional activity of $\mathrm{C} / \mathrm{EBP} \beta / \delta$ and PPAR $\gamma$. Our results provide the evidence that the GH-Stat5A/B signaling pathway stimulates adipogenesis by two distinct steps through stimulating $\mathrm{C} / \mathrm{EBP} \beta / \delta$ and $\operatorname{PPAR} \gamma$ activities.

\section{Materials and methods}

\section{Materials}

3T3-L1 cells and C3H10T1/2 cells were obtained from the Human Science Research Resources Bank (Osaka, Japan). Growth hormone, insulin, 3-isobutyl-2-methylxanthine, and cycloheximide were purchased from Wako Pure Chemical Industries Ltd. (Osaka, Japan). Dexamethasone and triiodothyronine were purchased from ICN Biomedicals, Inc. (Aurora, OH, USA). Biotin, epidermal growth factor (EGF), fetuin, and anti- $\beta$-actin antibody were purchased from Sigma. The anti-PPAR $\gamma$ antibody, anti-C/EBP $\beta$ antibody, and anti-C/EBP $\delta$ antibody were obtained from Santa Cruz Biotechnology, Inc. (Santa Cruz, CA, USA) and the antiStat5 antibody and anti-proliferating cell nuclear antigen (PCNA) antibody were from BD Transduction Laboratory, Inc. (Lexington, KY, USA).

\section{Cell culture}

3T3-L1 cells and C3H10T1/2 cells were grown and maintained in Dulbecco's modified Eagle's medium (DMEM) supplemented with $4.5 \mathrm{~g} / 1$ glucose, $100 \mathrm{U} / \mathrm{ml}$ penicillin, $100 \mu \mathrm{g} / \mathrm{ml}$ streptomycin, and $10 \%$ FCS in $5 \%$ $\mathrm{CO}_{2}$ at $37^{\circ} \mathrm{C}$. For the induction of adipogenesis, 3T3-L1 cells were grown to confluence. Two days after confluence, the medium was changed to differentiation medium containing $1 \mu \mathrm{M}$ dexamethasone, $0.5 \mathrm{mM}$ 3-isobutyl-1-methylxanthine, and $5 \mu \mathrm{g} / \mathrm{ml}$ insulin (MDI) in serum-free medium consisting of $5 \mu \mathrm{g} / \mathrm{ml}$ transferrin, $2 \mathrm{nM}$ triiodothyronine, $30 \mathrm{ng} / \mathrm{ml} \mathrm{EGF,} 1 \mu \mathrm{M}$ biotin, and $200 \mu \mathrm{g} / \mathrm{ml}$ fetuin in DMEM (Tominaga et al. 2002). After treatment with differentiation medium, the medium was changed to maintenance medium (serumfree medium).

\section{Oil Red O staining}

On day 6, cells were stained with Oil Red O as follows. The cells were washed with PBS and fixed with $10 \%$ formalin in PBS for $20 \mathrm{~min}$. After fixing, cells were washed twice with PBS and once with $60 \%$ isopropylalcohol. The cells were stained with $60 \%$ Oil Red O solution from a stock of $0.25 \mathrm{~g}$ Oil Red $\mathrm{O}$ in $50 \mathrm{ml}$ isopropyl-alcohol for $1 \mathrm{~h}$ (Sigma). To quantify the incorporation of lipid, the area stained with Oil Red $\mathrm{O}$ was measured using an Image Pro Plus analyzer (MediaCybernetics, Inc., Silver Spring, MD, USA).

\section{Constructs and luciferase reporter assay}

pcDNA1 Stat5A expression vector, pcDNA1 Stat5B expression vector, and $\beta$-casein promoter linked to a luciferase reporter gene $(p Z Z 1-L u c)$ were kindly 
provided by Yamashita et al. (2003). Stat5A-Y694F was generated by substituting phenylalanine for tyrosine at 694 amino acid and subcloned into a pcDNA1 expression vector (Invitrogen Life Technologies). The sequence of the mutant cDNA was confirmed by DNA sequence analysis. GHR cDNA (pMet-IG-mGHR) was a kind gift from Dr John J Kopchick (Ohio University, Ohio). pCMX-PPAR $\gamma$ expression vector and PPAR $\gamma$ binding element (PPRE)-luciferase construct (PPREx3TK-Luc) were described previously (Kliewer et al. 1994). $\mathrm{C} / \mathrm{EBP} \beta$ cDNA and $\mathrm{C} / \mathrm{EBP} \delta$ cDNA were kindly provided by Dr Shizuo Akira (Tanaka et al. 1997). PPAR $\gamma$ promoter fused to a luciferase construct was described previously (Ichida et al. 2004). Transient transfection was carried out using FuGENE 6 (Roche Applied Science) following the manufacturer's protocol. The total amount of DNA added to each well was equalized using an empty vector. Luciferase assay was performed in duplicate according to the protocol of the dual-luciferase reporter assay system (Promega). Briefly, 2 days after transfection, cells were lysed and luciferase activity was determined using specific substrates in a luminometer. Transfection efficiency was normalized by co-transfection with TK-Renilla luciferase construct (Promega).

\section{Generation of adenovirus}

Adenoviruses carrying Stat5A, Stat5B, Stat5A-Y694F, $\mathrm{C} / \mathrm{EBP} \beta, \mathrm{C} / \mathrm{EBP} \delta$ and $\mathrm{PPAR} \gamma$ were constructed using ViraPower Adenoviral Expression System (Invitrogen Life Technologies). Briefly, cDNA was inserted into TOPO pENTR vector and was recombined to the adenovirus expression plasmid pAd/CMV/V5-DEST. The pAd/CMV/V5-DEST plasmid with cDNA was digested with the PacI endonuclease and transfected with HEK293A cells. The medium supernatant containing adenovirus was collected and titrated according to the manufacturer's instructions. At $100 \%$ confluency, 3T3-L1 cells were infected with adenovirus at multiplicity of infection (MOI) of 500 with $0.5 \mu \mathrm{g} / \mathrm{ml}$ poly-L-lysin (Sigma; Orlicky \& Schaack 2001) in DMEM containing 2\% FCS for $6 \mathrm{~h}$. C3H10T1/2 cells were infected with adenovirus at MOI of 200 in DMEM containing $10 \%$ FCS.

\section{Western blot analysis}

To prepare whole cell lysates, cells were washed twice with ice-cold PBS and solubilized in lysis buffer $(50 \mathrm{mM}$ Tris, $150 \mathrm{mM} \mathrm{NaCl}, 1 \mathrm{mM}$ EDTA, $1 \% \mathrm{NP}-40,0 \cdot 25 \%$ Na-deoxycholate, $2 \mu \mathrm{g} / \mathrm{ml}$ aprotinin, $2 \mu \mathrm{g} / \mathrm{ml}$ leupeptin, $2 \mu \mathrm{g} / \mathrm{ml}$ pepstatinA, $0.5 \mathrm{mM}$ phenylmethylsulfonyl fluoride, and $1 \mathrm{mM}$ dithiothreitol). Lysates were centrifuged for $20 \mathrm{~min}$ at $4{ }^{\circ} \mathrm{C}$ at $12000 \mathrm{~g}$ and supernatants were collected. For cell fractionation, 3T3-L1 cells were washed twice with ice-cold PBS and solubilized in hypotonic lysis buffer $(10 \mathrm{mM}$ Hepes $(\mathrm{pH}$ $7 \cdot 8$ ), $10 \mathrm{mM} \mathrm{KCl}, 0 \cdot 1 \mathrm{mM}$ EDTA (pH 8.0), $2 \mu \mathrm{g} / \mathrm{ml}$ aprotinin, $2 \mu \mathrm{g} / \mathrm{ml}$ leupeptin, $2 \mu \mathrm{g} / \mathrm{ml}$ pepstatin $\mathrm{A}$, $0.5 \mathrm{mM}$ phenylmethylsulfonyl fluoride, and $1 \mathrm{mM}$ dithiothreitol). Lysates were centrifuged at $12000 \mathrm{~g}$ for $20 \mathrm{~min}$ and supernatants were used as cytosol extracts. The pellet was then lysed with hypertonic buffer $(50 \mathrm{mM}$ Hepes $(\mathrm{pH} \mathrm{7} 8), 420 \mathrm{mM} \mathrm{KCl}, 0 \cdot 1 \mathrm{mM}$ EDTA (pH 8•0), $5 \mathrm{mM} \mathrm{MgCl} 2,2 \%$ glycerol, $2 \mu \mathrm{g} / \mathrm{ml}$ aprotinin, $2 \mu \mathrm{g} / \mathrm{ml}$ leupeptin, $2 \mu \mathrm{g} / \mathrm{ml}$ pepstatin A, $0.5 \mathrm{mM}$ phenylmethylsulfonyl fluoride, and $1 \mathrm{mM}$ dithiothreitol) and supernatants collected after centrifugation (12 $000 \mathrm{~g}$ for $20 \mathrm{~min}$ ) were used as nuclear extracts. The protein concentration was determined by the Lowry method using the DC reagent (Bio-Rad Laboratories). The same amount of samples was separated by SDS-PAGE and transferred electrophoretically to nitrocellulose membranes. The amount of protein was checked by Ponceau S staining. Membranes were blocked in 5\% BSA in Tris-buffered saline (TBS). Thereafter, the membranes were immunoblotted with anti-C/EBP $\beta$ (1:250), anti-C/EBP $\delta$ (1:250), anti-PPAR $\gamma$ (1:250), anti-Stat5 (1:250), anti- $\beta$-actin (1:2000), or antiPCNA (1:5000), and developed with horseradish peroxidase-coupled anti-mouse IgG antibodies, followed by enhancement with ECL detection kits (Amersham Biosciences) or SuperSignal West Dura Extended Duration Substrate Antibodies (Pierce Chemical Co., Rockford, IL, USA). The protein bands were digitally imaged for densitometry using Scion software (Scion Corp., Frederick, MA, USA).

\section{RNA preparations and real-time reverse transcription- PCR (RT-PCR)}

Total RNA was prepared with RNeasy Mini Kit (Qiagen) according to the manufacturer's instructions, and cDNA was generated using a random primer and reverse transcriptase (Superscript II, Invitrogen Life Technologies) according to the manufacturer's instructions. Quantification of mRNA expression was carried out using a LightCycler amplification and detection system (a LightCycler-FastStart DNA Master SYBR Green I; Roche Diagnostics). GAPDH gene was used as an internal standard gene for quantification. PCR product of each gene was inserted into a pGEM T vector (Promega) and used as a standard dilution with a known number of copies. Conditions of amplification were: an initial step $\left(94^{\circ} \mathrm{C}, 10 \mathrm{~min}\right)$ followed by 35 cycles consisting of a denaturation step $\left(94^{\circ} \mathrm{C}, 15 \mathrm{~s}\right)$, primer annealing $\left(55^{\circ} \mathrm{C}\right.$ for PPAR $\gamma 2,57^{\circ} \mathrm{C}$ for glyceraldehyde-3 phosphate dehydrogenase (GAPDH), $5 \mathrm{~s})$ and an extension step $\left(72^{\circ} \mathrm{C}, 10 \mathrm{~s}\right)$. The products for PPAR $\gamma 2$ and GAPDH were detected at $85^{\circ} \mathrm{C}$. 
Specific primers for PPAR $\gamma 2$ (forward primer: 5'-GGTGAAACTCTGGGAGATTC-3'; reverse primer: 5'-CAACCATTGGGTCAGCTCTT-3'), GAPDH (forward primer: $5^{\prime}$-TGAACGGGAAGCTCACTGG-3'; reverse primer: $5^{\prime}$-TCCACCACCCTGTTGCTGTA-3' ${ }^{\prime}$ ).

\section{cDNA microarray analysis}

The quality of extracted total RNA was confirmed with an Agilent Technologies 2100 Bioanalyzer (Agilent Technologies, Palo Alto, CA, USA). An IntelliGene II Mouse CHIP (Takara, Shiga, Japan), on which 4277 mouse genes were spotted, was utilized to perform the cDNA microarray analysis. Cy3- and Cy5-labeled cDNA were prepared with mRNA isolated from control cells and GH-treated cells. Both were mixed and hybridized to the CHIP. The hybridized CHIP was scanned using an Affimetrix 418 Array Scanner (Woburn, MA, USA) and ImaGene software (BioDiscovery, Los Angeles, CA, USA). The experiments were performed thrice independently. To confirm the data, RT-PCR was performed using Taq DNA Polymerase (Promega) and specific primers for interleukin-4 (IL-4) receptor (forward primer: $5^{\prime}$-CTGTGGGCTGTCTGATTTTG-3'; reverse primer: 5'-CTGGGTTCCTTGTAGGTCAC-3'), vascular endothelial growth factor (VEGF) A (forward primer: $5^{\prime}$-TGTGCAGGCTGCTGTAACGA-3'; reverse primer: $5^{\prime}$-CGCCTTGGCTTGTCACATCT-3'), TWIST (forward primer: 5'-ATGGACAGTCTAGAGACTCTG-3'; reverse primer: $5^{\prime}$-GCATTTTACCATGGGTCATC-3 ${ }^{\prime}$ ), and $\beta$-actin (forward primer: $5^{\prime}$-TGGGAATGGGTCAGAAGGACTC-3'; reverse primer: 5'-AGAGGCATACAGGGACAGCACA- $3^{\prime}$ ). $\beta$-Actin was used as an internal standard.

\section{Statistical analysis}

All data are expressed as the mean \pm s.E.M. Results were analyzed for statistically significant differences using Student's $t$-test or ANOVA followed by Bonferroni multiple comparison post hoc test (Stat View software, SAS Institute, Cary, NC, USA). Statistical significance was set at $P<0 \cdot 05$.

\section{Results}

\section{GH stimulates adipogenesis of 3T3-L1 cells}

In order to investigate the effect of $\mathrm{GH}$ on adipogenesis, 3T3-L1 cells were treated with $50 \mathrm{ng} / \mathrm{ml} \mathrm{GH}$ in the presence of $10 \%$ FCS as the first experimental condition. $\mathrm{GH}$ could not induce adipogenesis, indicating that GH by itself has little effect on the initiation of adipogenesis (Fig. 1A). Next, we treated 3T3-L1 cells with differentiation medium for 2 days, and $50 \mathrm{ng} / \mathrm{ml} \mathrm{GH}$ were added to both differentiation and maintenance media to examine the effect of GH. Since GH is intrinsically contained in FCS, serum-free medium was utilized (Smith et al. 1988). On day 6, the area of Oil Red O staining did not show any significant difference between cells treated with or without GH (Fig. 1B). Treating cells with differentiation medium for 2 days is the most commonly used protocol for adipogenesis (Rubin $e t$ al. 1978). In this condition, most cells were strongly induced to differentiate into adipocytes even in serumfree medium (Fig. 1B). We speculated that such a potent induction protocol is likely to mask the effect of GH on adipogenesis. In order to detect the effect of $\mathrm{GH}$, we modified the induction protocol by reducing the incubation time with differentiation medium. When cells were treated with differentiation medium for $3 \mathrm{~h}$ followed by incubation with maintenance medium, addition of $\mathrm{GH}$ to both differentiation and maintenance media showed the significant initiation of adipogenesis when compared with control (Fig. 1B and C). The effect of $\mathrm{GH}$ was in a dose-dependent manner and $50 \mathrm{ng} / \mathrm{ml}$ GH showed the maximum effect on adipogenesis (Fig. 1D). Although more than $50 \mathrm{ng} / \mathrm{ml} \mathrm{GH}$ showed the trend of decrease in $\mathrm{GH}$ effect, there was no significant difference.

\section{GH stimulates adipogenesis of 3T3-L1 cells through the early induction of PPAR $\gamma 2$ expression, not $\mathrm{C} / \mathrm{EBP} \beta$ and $\mathrm{C} / \mathrm{EBP} \delta$}

To examine whether $\mathrm{GH}$ has any effects on the expression of $\mathrm{C} / \mathrm{EBP} \beta, \mathrm{C} / \mathrm{EBP} \delta$ and $\operatorname{PPAR} \gamma$, we determined the expression of these transcription factors under the culture condition in which GH shows its stimulatory effect on adipogenesis. Although both $\mathrm{C} / \mathrm{EBP} \beta$ and $\mathrm{C} / \mathrm{EBP} \delta$ were transiently induced after $3 \mathrm{~h}$ adipogenic induction, $\mathrm{GH}$ did not affect the expression of $\mathrm{C} / \mathrm{EBP} \beta$ and $\mathrm{C} / \mathrm{EBP} \delta$ (Fig. 2A). PPAR $\gamma$ has two isoforms which are generated by alternative splicing of mRNA (PPAR $\gamma 1$ and PPAR $\gamma 2$ ). Whereas PPAR $\gamma 1$ is expressed in several tissues including adipose tissue, PPAR $\gamma 2$ is specifically expressed in adipose tissue (Vidal-Puig et al. 1997). PPAR $\gamma 1$ was expressed in 3T3-L1 preadipocytes, and the expression of PPAR $\gamma 1$ increased gradually as adipogenesis proceeded (Fig. 2A). PPAR $\gamma 2$ was not expressed in 3T3-L1 preadipocytes, and the expression of PPAR $\gamma 2$ increased gradually as adipogenesis proceeded, and was induced earlier in cells treated with $\mathrm{GH}$ when compared with cells without GH (Fig. 2A and B). Quantitative RT-PCR analysis also showed a significant up-regulation of PPAR $\gamma 2$ mRNA expression in the cells treated with GH (Fig. 2C). To examine whether this enhanced PPAR $\gamma$ expression is due to increased synthesis or decreased degradation, 3T3-L1 cells were transfected with PPAR $\gamma$ expression vector and cultured with or without $\mathrm{GH}$ for $16 \mathrm{~h}$. After incubation with $\mathrm{GH}, 10 \mu \mathrm{g} / \mathrm{ml}$ cycloheximide was added to inhibit 


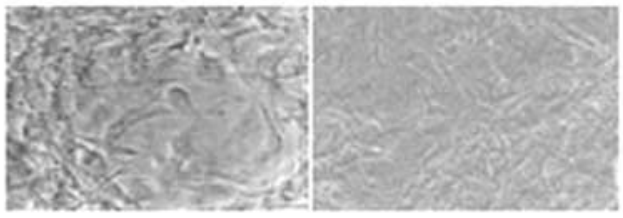
$-\mathrm{GH}$ $+\mathrm{GH}$
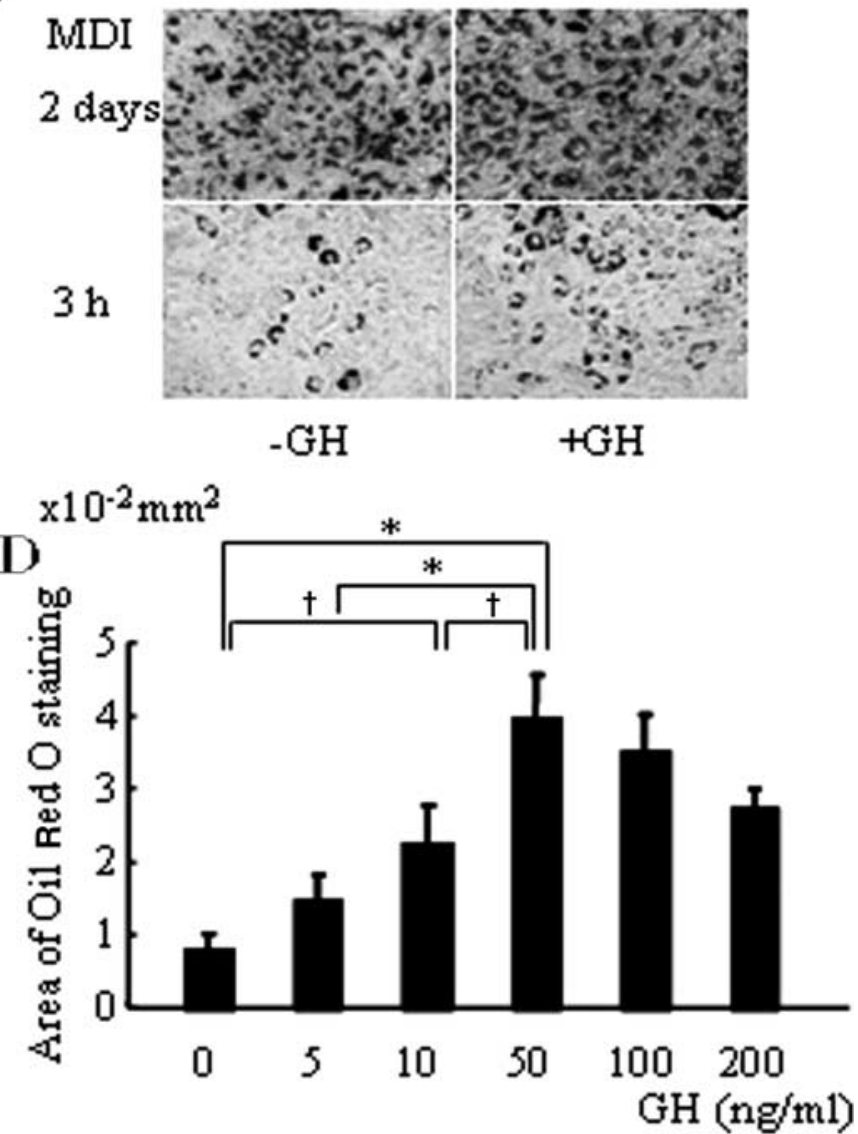

Figure 1 Stimulatory effect of GH on adipogenesis. (A) 3T3-L1 cells were incubated with or without $50 \mathrm{ng} / \mathrm{ml}$ GH in DMEM containing $10 \%$ FCS for 14 days, and stained with Oil Red O. No adipocytes were observed. (B and C) 3T3-L1 cells were treated with differentiation medium for either 2 days or $3 \mathrm{~h}$ followed by incubation with maintenance medium. GH was added to both differentiation and maintenance media. On day 6, the cells were stained with Oil Red $O(B)$ and the stained area was measured in cells treated with 3-h $\mathrm{MDI}$ (C). While 2-day treatment did not show any significant difference between cells treated with or without GH, 3-h treatment showed the stimulation of adipogenesis in the cells treated with $\mathrm{GH}$. (D) Dose-dependent manner of GH effect. 3T3-L1 cells were induced to differentiate with 3-h MDI treatment and GH was added at the indicated concentration $(0-200 \mathrm{ng} / \mathrm{ml})$. On day 6 , the cells were stained with Oil Red $\mathrm{O}$ and the stained area was measured. Experiments were repeated independently five times. Statistically significant difference was: ${ }^{*} P<0.001$ and ${ }^{\dagger} P<0.05$.

de novo protein synthesis, and whole cell lysates were collected at indicated periods. Western blot analysis of $\operatorname{PPAR} \gamma$ showed no difference in the degradation rate between cells treated with or without GH (Fig. 2D). These findings suggest that GH exerts its effect through the up-regulation of $\mathrm{PPAR} \gamma$ synthesis.

\section{GH facilitates the nuclear translocation of Stat5 during the early stage of adipogenesis}

To address whether Stat5A and $5 \mathrm{~B}$ are implicated in GH-mediated adipogenesis, we first examined the intracellular localization of Stat 5 by subcellular fractionation. Consistent with the previous report (Richter et al. 2003), localization of Stat5 in the nucleus significantly increased in cells treated with GH at 3, 6, and $12 \mathrm{~h}$ (Fig. 3A and B). Immunofluorescence experiments also showed nuclear localization of Stat5 as early as $1 \mathrm{~h}$ after GH stimulation (data not shown). As shown in Fig. 3B, in 3T3L1 cells treated with $\mathrm{GH}$, nuclear Stat5 expression increased at $3 \mathrm{~h}$, significantly decreased thereafter and increased after $24 \mathrm{~h}$. Similar to our data, Nanbu-Wakao et al. (2002) reported the tyrosine phosphorylation of Stat5 during adipogenesis using 3T3-L1 cells treated with standard 2-day MDI in the presence of $10 \%$ FCS. In contrast, in 3T3-L1 cells treated without GH, nuclear Stat5 expression increased after $24 \mathrm{~h}$, indicating that Stat5 is activated independent of $\mathrm{GH}$ in this condition (Fig. 3B, open columns). Component of maintenance medium or growth factor(s) produced by 3T3-L1 cells during adipogenesis may be involved in Stat5 activation. Indeed, EGF, which is a component of maintenance 
A

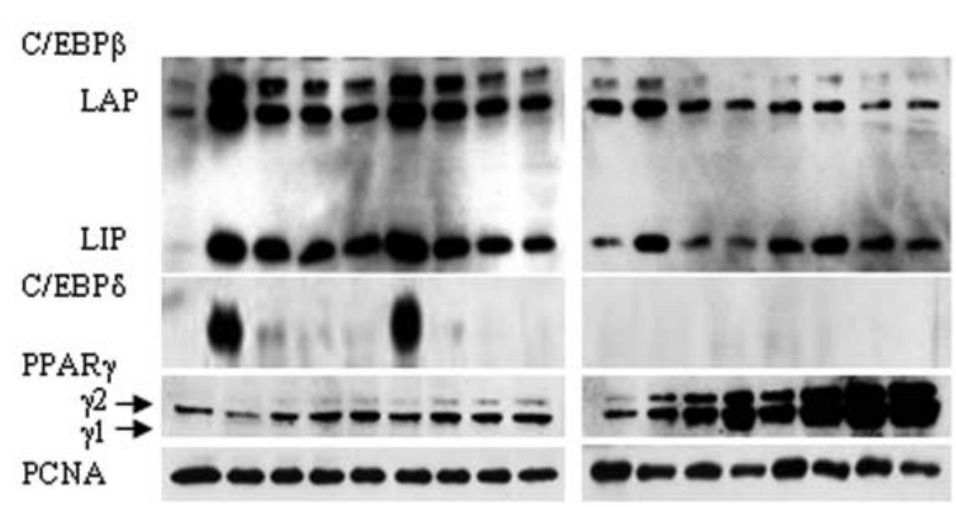

Pre $\frac{3 \quad 6 \quad 9 \quad 12}{-\mathrm{GH}} \frac{3 \quad 6 \quad 9 \quad 12}{+\mathrm{GH}} \frac{24487296}{-\mathrm{GH}} \frac{24487296 \mathrm{~h}}{+\mathrm{GH}}$
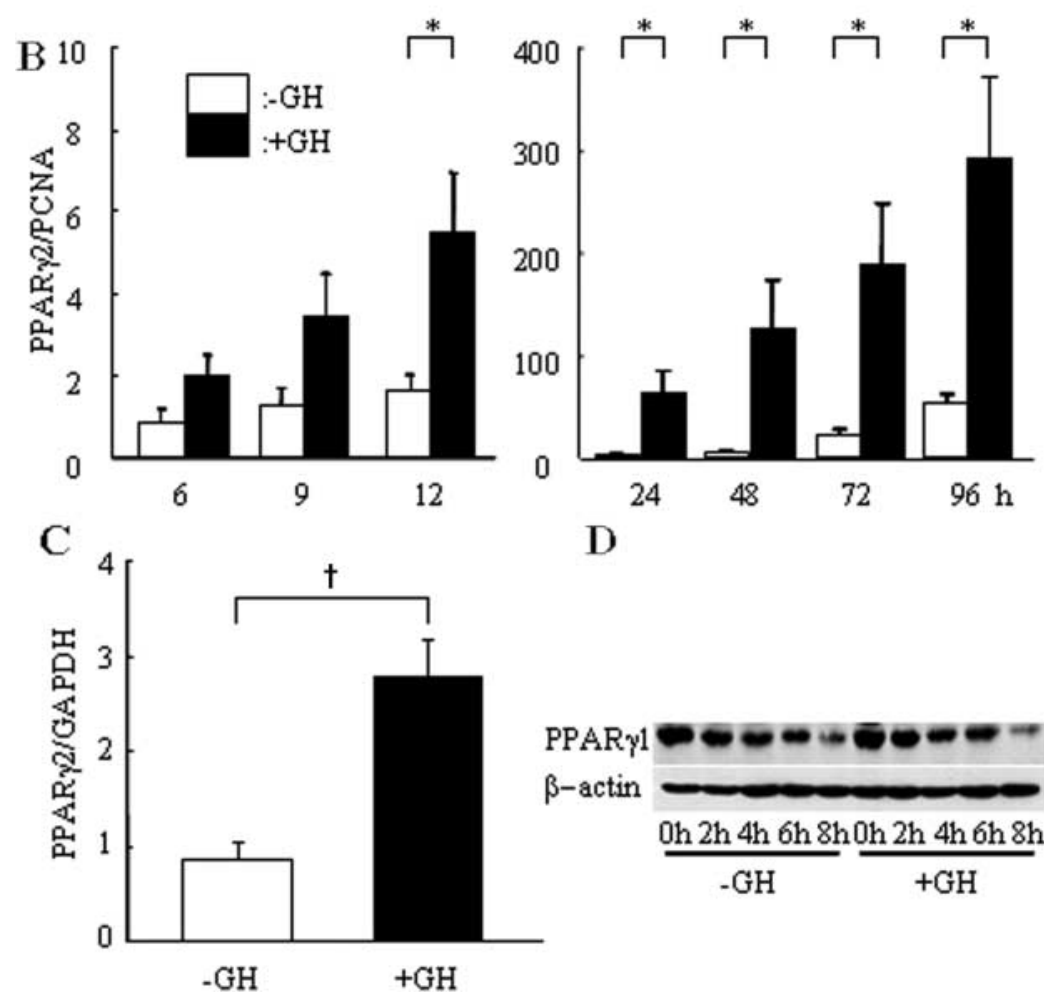

D

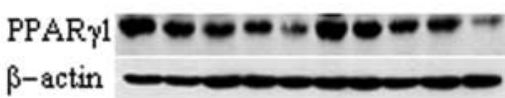

$0 \mathrm{~h} 2 \mathrm{~h} 4 \mathrm{~h} 6 \mathrm{~h} 8 \mathrm{~h} 0 \mathrm{~h} 2 \mathrm{~h} 4 \mathrm{~h} 6 \mathrm{~h} 8 \mathrm{~h}$

$-\mathrm{GH}$

$+\mathrm{GH}$

Figure 2 Effect of GH on the expression of C/EBP $\beta$, C/EBP $\delta$, and PPAR $\gamma$. 3T3-L1 cells were induced to differentiate by $3-h$ incubation with differentiation medium followed by incubation with maintenance medium, and $50 \mathrm{ng} / \mathrm{ml} \mathrm{GH}$ were added to both differentiation and maintenance media. (A) Nuclear extracts were collected at the indicated periods and then subjected to western blot analysis of PPAR $\gamma, \mathrm{C} / \mathrm{EBP} \beta, \mathrm{C} / \mathrm{EBP} \delta$ and PCNA. Earlier induction of PPAR $\gamma 2$ expression was noted in the cells treated with $\mathrm{GH}$. (B) The protein expression of PPAR $\gamma 2$ was quantified by densitometry from four independent experiments. Densities were normalized against the density of PCNA. (C) Quantitative RT-PCR analysis of mRNA expression of PPAR $\gamma 2$. Total RNA was extracted $3 \mathrm{~h}$ after adipogenic induction. Data were normalized by the expression of GAPDH. (D) Degradation of PPAR $\gamma$. Whole cell lysates of 3T3-L1 cells transfected with PPAR $\gamma$ expression vector were subjected to western blot analysis of PPAR $\gamma$ and $\beta$-actin at the indicated periods after the addition of $10 \mu \mathrm{g} / \mathrm{ml}$ cycloheximide. No difference in degradation rate was noted between cells incubated with or without GH. LAP, liverenriched transcriptional activator protein; LIP, liver-enriched transcriptional inhibitory protein. Statistically significant differences were: ${ }^{*} P<0.05$ and ${ }^{\dagger} P<0.01$. 
A
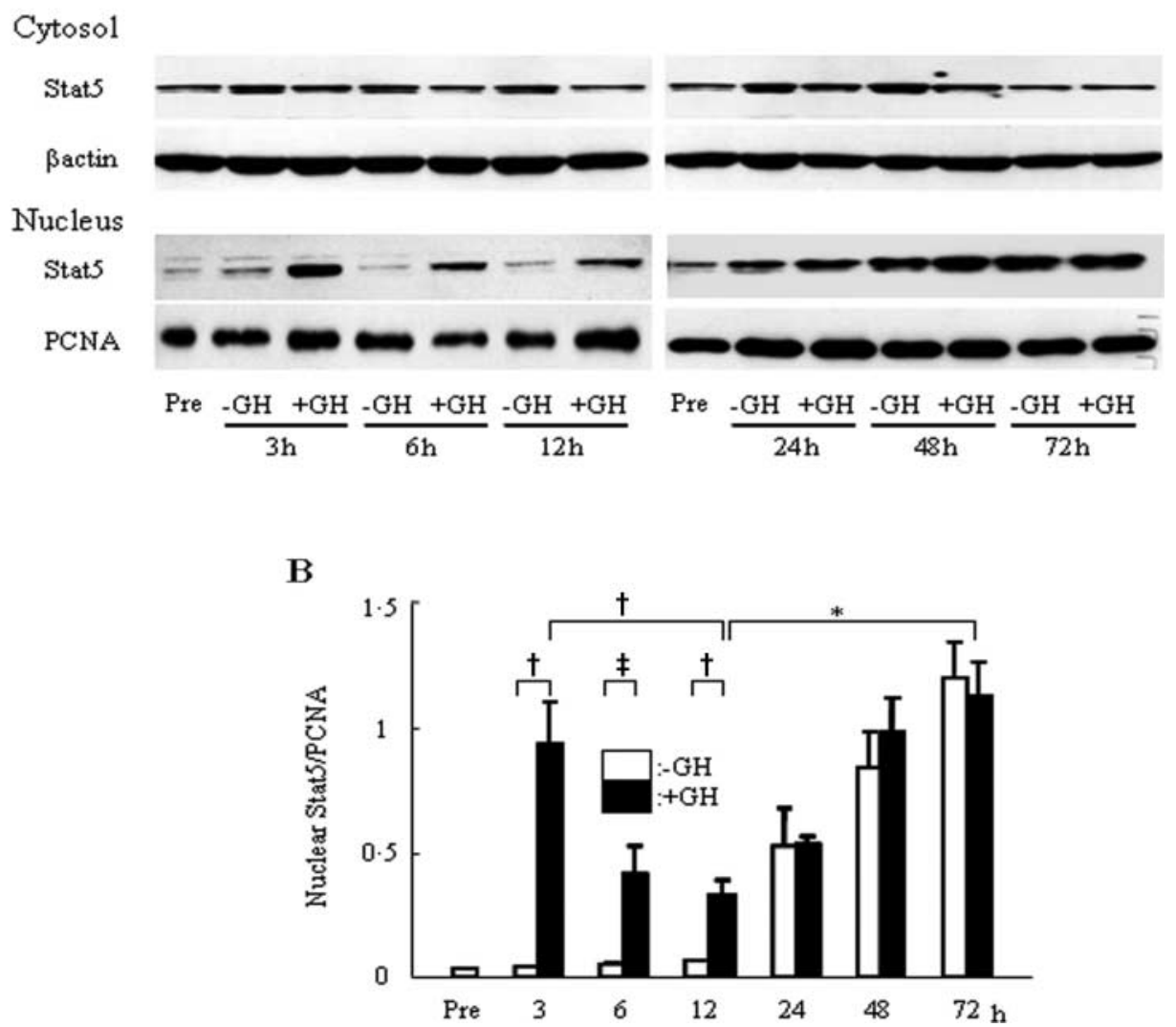

Figure $3 \mathrm{GH}$ facilitates the nuclear translocation of Stat5. 3T3-L1 cells were incubated with differentiation medium for $3 \mathrm{~h}$ followed by incubation with maintenance medium, and $50 \mathrm{ng} / \mathrm{ml} \mathrm{GH}$ were added to both differentiation and maintenance media. (A) Lysates from cytosol extracts and nuclear extracts were prepared at the indicated periods and then subjected to western blot analysis of Stat5, $\beta$-actin (cytosol extracts), and PCNA (nuclear extracts). (B) The protein expression of nuclear Stat5 was quantified by densitometry from three independent experiments. Densities were normalized against the density of PCNA. Statistically significant differences were: ${ }^{\star} P<0.001,{ }^{\dagger} P<0.01$, and ${ }^{\ddagger} P<0.05$.

medium, was reported to activate Stat5 (Ruff-Jamison et al. 1995). Combined together, nuclear Stat5 expression might be regulated by the combination of GH-dependent activation in the early stage of adipogenesis and GH-independent activation in the later stage of adipogenesis. Although the exact reason why levels of nuclear Stat5 fluctuate in this way in cells with $\mathrm{GH}$ and the outcome of this fluctuation are not clear, $\mathrm{GH}$ is thought to function at an early stage of adipogenesis. In conclusion, GH facilitates the nuclear translocation of Stat5 and the GH-Stat5 signaling pathway is possibly involved in the stimulatory effect of $\mathrm{GH}$ in the early stage of adipogenesis.

\section{Stat5A-Y694F suppresses the stimulatory effect of GH in MDI-induced adipogenesis, while Stat5A and 5B enhance MDI-induced adipogenesis}

In order to examine whether the adipogenic effect of GH is mediated through Stat $5 \mathrm{~A}$ and/or $5 \mathrm{~B}$, we used a point mutant of Stat5A (Stat5A-Y694F; Nanbu-Wakao et al. 2002). First, we examined the effect of Stat5A$\mathrm{Y} 694 \mathrm{~F}$ on the transcriptional activity of Stat5A and 5B in 3T3-L1 cells by a luciferase reporter assay using a $\beta$-casein gene promoter luciferase construct containing a Stat5 response element. In the presence of $\mathrm{GH}$, Stat5A and 5B showed 21- and 7-fold enhancement of transcriptional activity respectively. Co-expression of Stat15A-Y694F showed approximately 80 and $70 \%$ suppression of the transcriptional activity of Stat5A and $5 \mathrm{~B}$ respectively, thus indicating that Stat5A-Y694F functions as a transcriptional suppressor for both the GH-Stat5A and the GH-Stat5B signaling pathways in 3T3-L1 cells (Fig. 4A).

Next, we explored the effect of overexpression of Stat5A-Y694F, Stat5A, and Stat5B in the adipogenic effect of GH using adenovirus gene transfer system. Two days after infection, the cells were induced to differentiate by 3-h incubation with differentiation medium followed by the incubation with maintenance medium, and GH was added to both differentiation and 

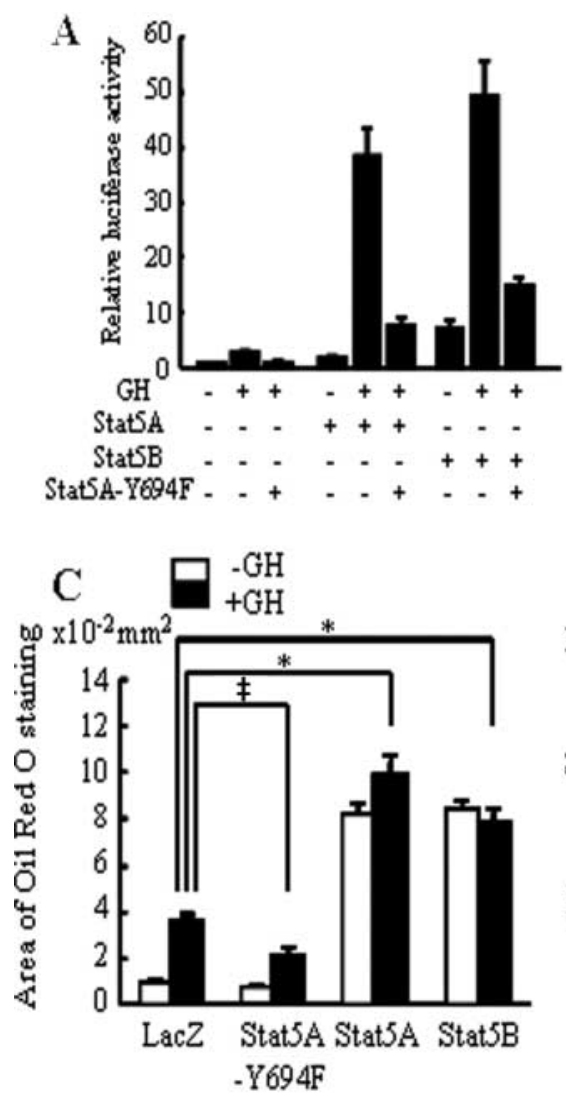

B

$-\mathrm{GH}$

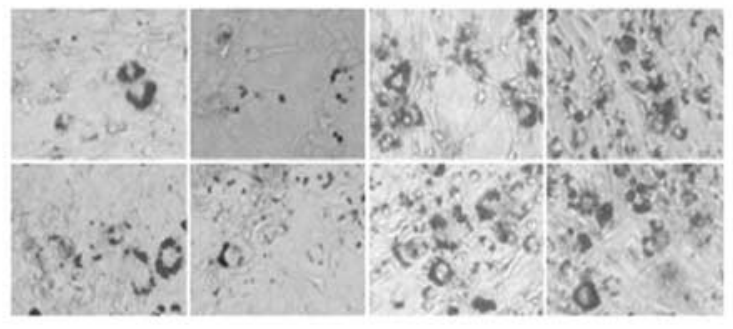

LacZ

\section{Stat5A} $-\mathrm{Y} 694 \mathrm{~F}$

D
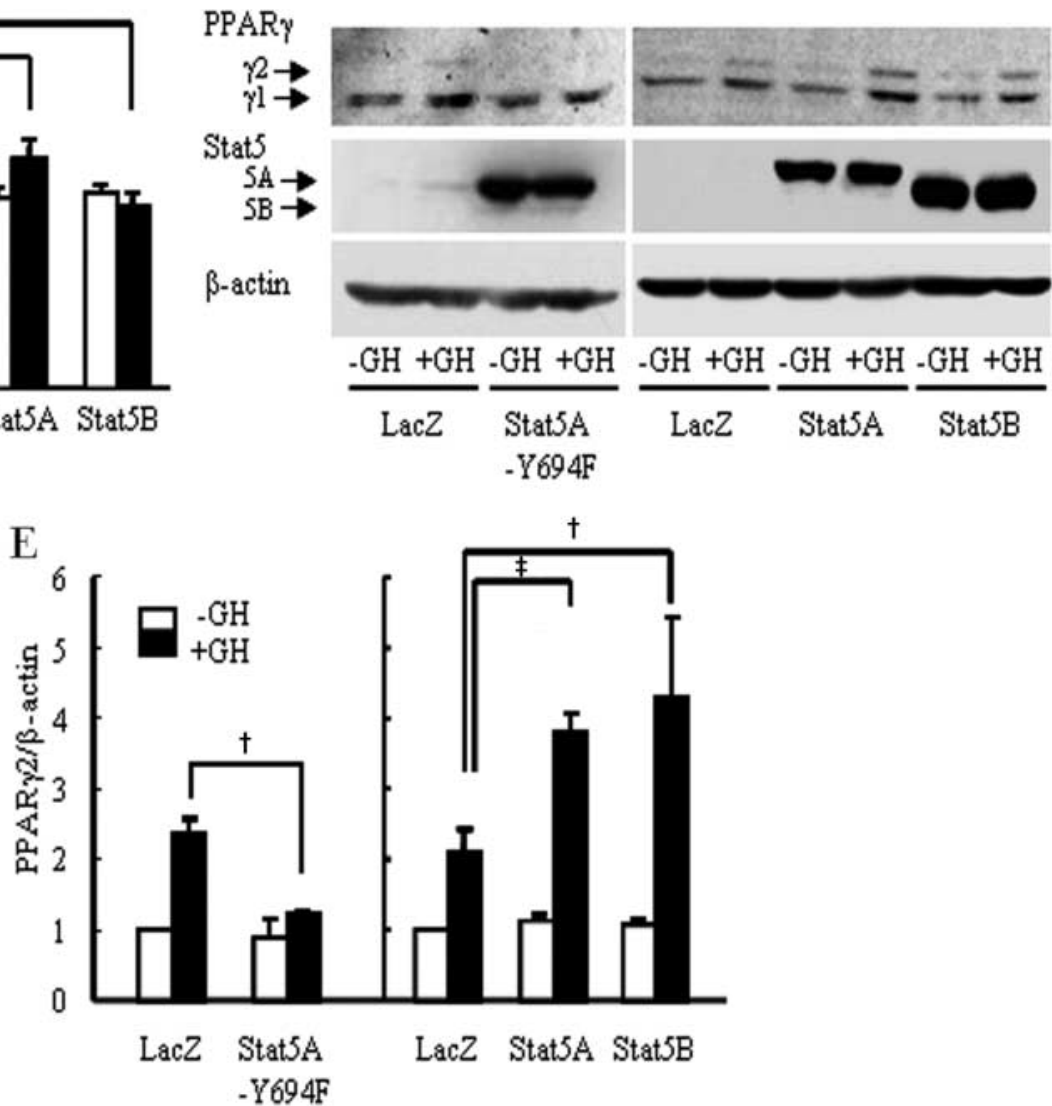

Figure 4 Involvement of the GH-Stat5A and the GH-Stat5B signaling pathway in MDI-induced adipogenesis. (A) Overexpression of Stat5A-Y694F suppressed the transcriptional activity of Stat5A and 5B. 3T3-L1 cells were transfected with pZZ1 (0.1 $\mu \mathrm{g})$, TK-Renilla reporter plasmid (5 $\mathrm{ng})$, GH receptor expression vector $(0.2 \mu \mathrm{g})$, Stat5A or 5B expression vector (0.05 $\mu \mathrm{g})$, and Stat5A-Y694F expression vector $(0.2 \mu \mathrm{g})$. The cells were treated with or without $500 \mathrm{ng} / \mathrm{ml} \mathrm{GH}$ in DMEM for $16 \mathrm{~h}$. Luciferase activity was measured using cell extracts and normalized by determining Renilla luciferase activity. Experiments were repeated independently five times. (B-E) Stat5AY694F suppressed the stimulatory effect of $\mathrm{GH}$ with the reduction of PPAR $\gamma 2$ expression, while Stat5A and 5B enhanced MDI-induced adipogenesis with the enhancement of PPAR $\gamma 2$ expression. 3T3-L1 cells were infected with LacZ, Stat5A, 5B, or Stat5A-Y694F adenovirus. After 2 days, the cells were induced to differentiate with differentiation medium for $3 \mathrm{~h}$ followed by incubation with maintenance medium, and $50 \mathrm{ng} / \mathrm{ml} \mathrm{GH}$ were added to both differentiation and maintenance media. On day 6 , the cells were stained with Oil Red O (B) and the stained area was measured (C). Whole cell lysates were collected $9 \mathrm{~h}$ after adipogenic induction and then subjected to western blot analysis of PPAR $\gamma$, Stat5, and $\beta$-actin (D). The protein expression of PPAR $\gamma 2$ was quantified by densitometry from three independent experiments. Densities were normalized against the density of $\beta$-actin $(E)$. Statistically significant differences were: ${ }^{\star} P<0.0001,{ }^{\dagger} P<0.01$, and ${ }^{\ddagger} P<0.05$. 
maintenance media. Overexpression of Stat5A-Y694F significantly suppresses the stimulatory effect of $\mathrm{GH}$ during MDI-induced adipogenesis with reduction of PPAR $\gamma 2$ expression (Fig. 4B-E), indicating the involvement of the $\mathrm{GH}-\mathrm{Stat} 5 \mathrm{~A} / 5 \mathrm{~B}$ signaling pathway in GH-mediated adipogenesis with modulation of PPAR $\gamma$ expression. In addition, western blot analysis of PPAR $\gamma$ $9 \mathrm{~h}$ after induction showed increased PPAR $\gamma 2$ expression in the cells infected with Stat5A or $5 \mathrm{~B}$ in a GH-dependent manner (Fig. 4D and E). Oil Red O staining at day 6 showed that overexpression of Stat5A or 5B stimulated MDI-induced adipogenesis, however, GH-dependent manner was not noted (Fig. 4B and C).

\section{Stat5A/5B stimulates C/EBP $\beta$ - and C/EBP $\delta$-induced adipogenesis}

Since PPAR $\gamma$ is induced by $\mathrm{C} / \mathrm{EBP} \beta$ and $\mathrm{C} / \mathrm{EBP} \delta$ during adipogenesis, we examined the relationship between $S t a t 5 A / 5 B$ and $C / E B P \beta / \delta$. Overexpression of Stat5A or $5 \mathrm{~B}$ in 3T3-L1 cells did not induce adipogenesis, indicating that Stat $5 \mathrm{~A} / 5 \mathrm{~B}$ by itself has little effect on the initiation of adipogenesis (Fig. 5A). When $\mathrm{C} /$ $\mathrm{EBP} \beta$ or $\mathrm{C} / \mathrm{EBP} \delta$ was overexpressed in 3T3-L1 cells and adipogenic program was initiated, co-expression of Stat5A or $5 \mathrm{~B}$ further enhanced $\mathrm{C} / \mathrm{EBP} \beta$ - and $\mathrm{C} / \mathrm{EBP} \delta$ induced adipogenesis (Fig. 5A and $\mathrm{B}$ ). Consistent with this result, Stat5A and 5B enhanced PPAR $\gamma 2$ expression in 3T3-L1 cells induced by $\mathrm{C} / \mathrm{EBP} \beta$ or $\mathrm{C} / \mathrm{EBP} \delta$ (Fig. $5 \mathrm{C}$ and $\mathrm{D}$ ). These findings demonstrate that $S t a t 5 \mathrm{~A} / 5 \mathrm{~B}$ is involved in adipogenesis in cooperation with $\mathrm{C} / \mathrm{EBP} \beta$ / $\delta$. To support this notion, we investigated the effect of Stat5A and $5 \mathrm{~B}$ on the transcriptional activity of C/ $\mathrm{EBP} \beta / \delta$ in the $P P A R \gamma$ gene promoter in 3T3-L1 cells. Overexpression of Stat5A and $5 \mathrm{~B}$ showed $145 \pm 16$ and $118 \pm 7 \%$ enhancement of $\mathrm{C} / \mathrm{EBP} \beta / \delta$ transcriptional activity respectively (Fig. 5E).

\section{Stat5A/5B stimulates adipogenesis in cooperation with PPAR $\gamma$}

Although Stat5A/5B enhanced PPAR $\gamma$ expression in $\mathrm{C} / \mathrm{EBP} \beta$ - and $\mathrm{C} / \mathrm{EBP} \delta$-induced adipogenesis of $3 \mathrm{~T} 3-\mathrm{L} 1$ cells, this does not exclude the possibility that Stat5A/5B has any effects on PPAR $\gamma$ activity. To examine this, we overexpressed PPAR $\gamma$ in 3T3-L1 cells. Overexpression of PPAR $\gamma$ induced adipogenesis, and co-expression of Stat5A or 5B stimulated PPAR $\gamma$ induced adipogenesis (Fig. 6A-C). To further confirm whether Stat5A/5B have any effects on PPAR $\gamma$ activity, a luciferase reporter assay using PPAR $\gamma$-binding element (PPRE)-luciferase construct was performed. The GHStat5A and the GH-Stat5B signaling pathways showed the trend of enhancement of the transcriptional activity of PPAR $\gamma$ in 3T3-L1 cells (Fig. 6D). However, due to the large variation in the data, there was no significant difference. We speculated that this outcome might be due to low transfection efficiency in 3T3-L1 cells. Therefore, to add further evidence, we investigated this effect using a multipotent mesenchymal cell line, C3H10T1/2, in which high transfection efficiency was achieved. In C3H10T1 / 2 cells, overexpression of Stat5A or $5 \mathrm{~B}$ also stimulated PPAR $\gamma$-induced adipogenesis and the GH-Stat5A and the GH-Stat5B signaling pathways significantly enhanced the transcriptional activity of PPAR $\gamma$ by $145 \pm 10$ and $191 \pm 3 \%$ in the presence of TGZ respectively (Fig. 6 A, B, and D). These findings indicate that Stat $5 \mathrm{~A} / 5 \mathrm{~B}$ functions by enhancing the transcriptional activity of PPAR $\gamma$.

\section{cDNA microarray analysis}

Although Stat5A/5B has been reported to have an important role in adipose tissue formation, and our data suggest that GH is likely to exert its effect through Stat5A/5B, there are possibly other pathways through which GH exerts its effect on adipogenesis. In fact, some genes have been reported to be induced in response to GH during adipogenesis in 3T3-F442A cells (Gurland et al. 1990, Clarkson et al. 1995, 1999, Shang et al. 2002, Huo et al. 2006). To investigate the mechanisms by which GH stimulates adipogenesis, we analyzed the gene expression profiles of 3T3-L1 cells treated with GH during MDI-induced adipogenesis using cDNA microarray analysis. Adipogenesis was induced with the incubation of differentiation medium in the presence or absence of GH, and total RNA was extracted $3 \mathrm{~h}$ after adipogenic induction. As we intended to detect the genes that affect PPAR $\gamma$ expression, we set the point of RNA extraction as $3 \mathrm{~h}$ after induction when PPAR $\gamma 2$ expression was not detected by western blot analysis. Gene expression was compared between cells treated with or without GH. cDNA microarray analysis was performed thrice, and genes which showed an increment or decrement of more than $1 \cdot 5$-fold in the fluorescence level at least twice were selected as up- and down-regulated genes respectively. The number of up- and down-regulated genes was 18 and 19 among the 4277 spotted genes respectively (Tables 1 and 2). Among the genes associated with adipogenesis, PPAR $\gamma$ was up-regulated, supporting our findings that GH induces PPAR $\gamma$ expression during adipogenesis.

In addition, the expression of genes coding for growth factors or growth factor receptors was altered. Among them, mRNA levels of IL-4 receptor, VEGF-A, and TWIST were confirmed using semiquantitative RT-PCR analysis (Fig. 7). Since the expression of these genes was altered by MDI-treatment alone, GH is thought to function under the influence of MDItreatment. So far, we have not been able to identify 

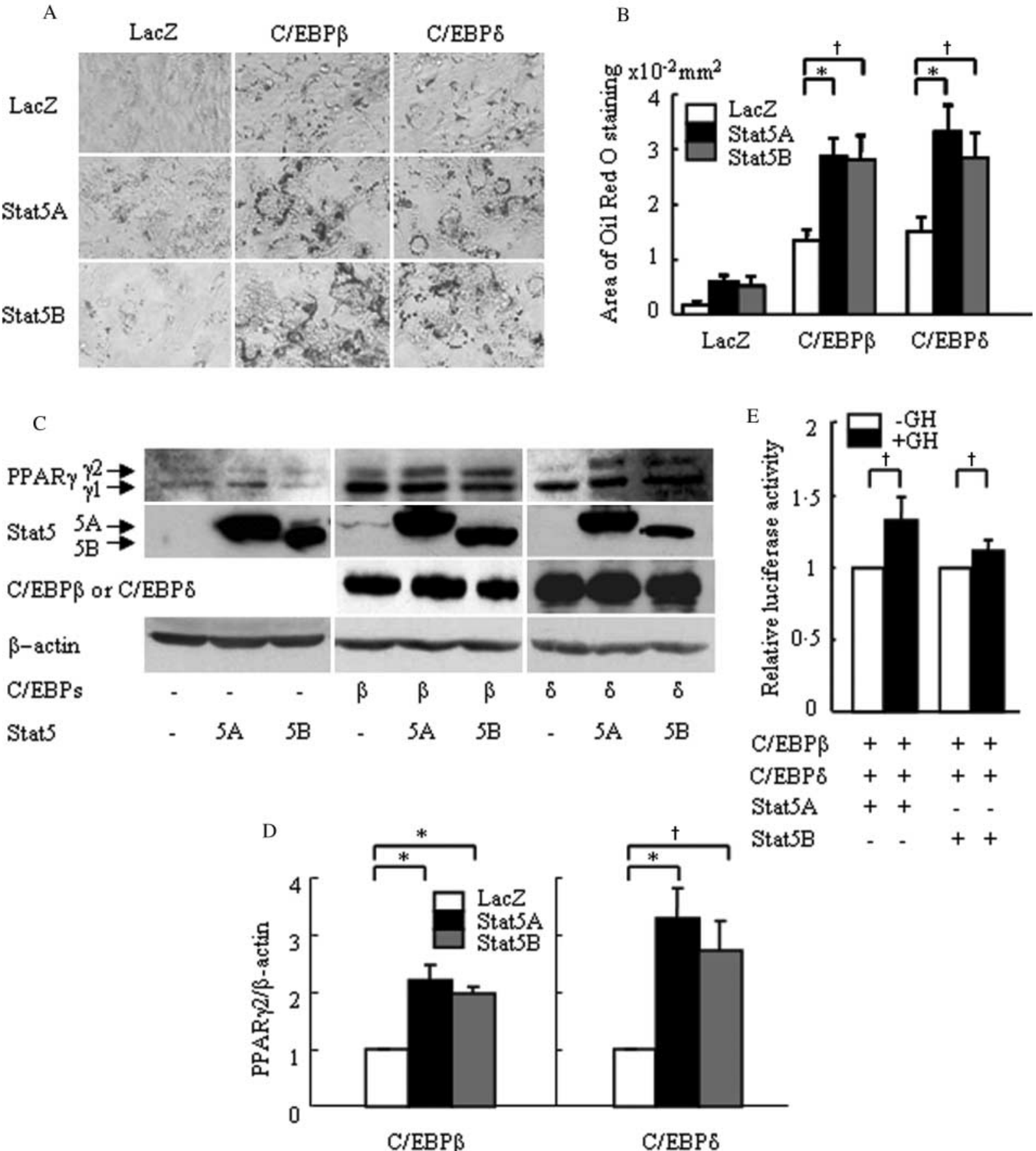

Stat5A $++-\cdot$

Stat 5 B $\quad-\quad++$

Figure 5 Stimulation of C/EBP $\beta$ - or C/EBP $\delta$-induced adipogenesis by Stat5A and 5B. 3T3-L1 cells were infected with LacZ, C/EBP $\beta$ or $\mathrm{C} / \mathrm{EBP} \delta$ adenovirus together with Stat5A or $5 \mathrm{~B}$ adenovirus, and cultured for 6 days in DMEM containing 10\% FCS. (A and B) The cells were stained with Oil Red $O(A)$ and the stained area was measured $(B)$. (C and $D)$ Whole cell lysates were collected and subjected to western blot analysis of PPAR $\gamma, \mathrm{C} / \mathrm{EBP} \beta, \mathrm{C} / \mathrm{EBP} \delta$, Stat5, and $\beta$-actin (C). The protein expression of PPAR $\gamma 2$ was quantified by densitometry from three independent experiments. Densities were normalized against the density of $\beta$-actin (D). (E) Enhancement of the transcriptional activity of $\mathrm{C} / \mathrm{EBP} \beta / \delta$ in the PPAR gene promoter by Stat5A and 5B. 3T3-L1 cells were transfected with $P P A R \gamma$ gene promoter luciferase construct $(0.1 \mu \mathrm{g})$, TK-Renilla reporter plasmid $(5 \mathrm{ng})$, GH receptor expression vector $(0.2 \mu \mathrm{g}), \mathrm{C} / \mathrm{EBP} \beta \mathrm{expression}$ vector $(0.025 \mu \mathrm{g}), \mathrm{C} / \mathrm{EBP} \delta$ expression vector $(0.025 \mu \mathrm{g})$, and Stat5A or $5 \mathrm{~B}$ expression vector $(0.05 \mu \mathrm{g})$. The cells were treated with $500 \mathrm{ng} / \mathrm{ml} \mathrm{GH}$ in DMEM for $16 \mathrm{~h}$. Luciferase activity was measured using cell extracts and normalized by determining Renilla luciferase activity. Experiments were repeated independently seven times. Statistically significant differences were: ${ }^{\star} P<0 \cdot 01$ and ${ }^{\dagger} P<0 \cdot 05$. 

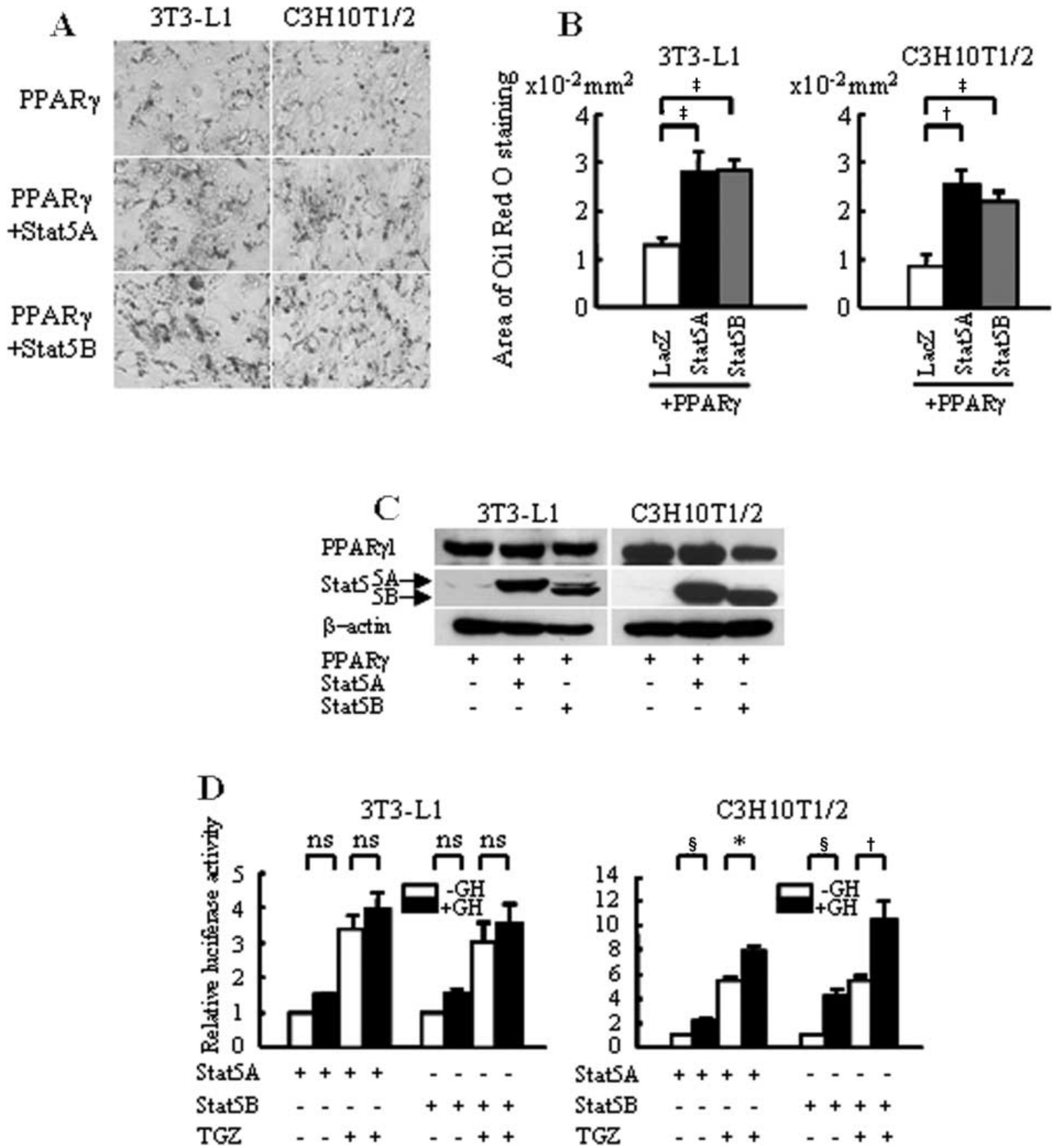

Figure 6 Stat5A and 5B stimulate adipogenesis in association with PPAR $\gamma$. (A-C) 3T3-L1 cells and C3H10T1/2 cells were infected with PPAR $\gamma$ adenovirus together with or without Stat5A or 5B adenovirus and cultured for 6 days in DMEM containing $10 \%$ FCS. The cells were stained with Oil Red $O(A)$ and the stained area was measured $(B)$. Whole cell lysates were collected and subjected to western blot analysis of PPAR $\gamma$, STAT5, and $\beta$-actin (C). (D) Stat5A and 5B enhance the transcriptional activity of PPAR $\gamma$. 3T3-L1 cells and C3H10T1/2 cells were transfected with $3 \times$ PPRE-Luc $(0.1 \mu \mathrm{g})$, TK-Renilla reporter plasmid $(5 \mathrm{ng})$, GH receptor expression vector $(0.2 \mu \mathrm{g})$, Stat5A or $5 \mathrm{~B}$ expression vector $(0.05 \mu \mathrm{g})$, and PPAR $\gamma$ expression vector $(0.05 \mu \mathrm{g})$. The cells were treated with either $500 \mathrm{ng} / \mathrm{ml}$ $\mathrm{GH}$ or $1 \mu \mathrm{M}$ troglitazone (TGZ), or both in DMEM for16 $\mathrm{h}$. Luciferase activity was measured using cell extracts and normalized by determining Renilla luciferase activity. Experiments were repeated independently five times. Statistically significant differences were: ${ }^{\star} P<$ $0.0001,{ }^{\dagger} P<0.001,{ }^{\ddagger} P<0.01$, and ${ }^{\S} P<0.05$. ns, not significant. 
Table 1 Up-regulated genes

Folds

\section{Gene}

Accession no.

NM_007836

NM_026179

NM_021434

NM_023118

NM_010557

NM_011035

NM_011106

NM_011198

NM 009505

NM_011521

NM_009178

NM_139198

NM_018884

NM_020573

NM_011660

NM_011146

NM_010135

NM 009846
Growth arrest and DNA damage-inducible 45

RIKEN cDNA 1300003D03 gene

Hypothetical protein, MNCb-3029

Disabled homolog 2 (Drosophila)

Interleukin 4 receptor, $\alpha$

p21 (CDKN1A)-activated kinase 1

Protein kinase inhibitor, $\gamma$

Prostaglandin-endoperoxide synthase 2

Vascular endothelial growth factor A

Syndecan 4

Sialyltransferase 4C ( $\beta$-galactosidase $\alpha$-2,3-sialytransferase)

Placenta-specific 8

semaF cytoplasmic domain associated protein 3

Oxysterol-binding protein-like $1 \mathrm{~A}$

Thioredoxin 1

Peroxisome proliferator activated receptor $\gamma$

Enabled homolog (Drosophila)

CD24a antigen

$1 \mathrm{st}$

st

$2 \cdot 7717$

$2 \cdot 3945$

$2 \cdot 0402$

$2 \cdot 1554$

$1 \cdot 8548$

$1 \cdot 8396$

$1 \cdot 6938$

$1 \cdot 7094$

$1 \cdot 5886$

$1 \cdot 7141$

$1 \cdot 4699$

$1 \cdot 4344$

$1 \cdot 3547$

$1 \cdot 4203$

1.5666

1.6205

1.5970

$1 \cdot 1468$

\section{$2 n d$}

nd

3.0877

3.0000

1.5520

1.7371

1.7473

1.4252

1.6333

$1 \cdot 4717$

1.5448

$1 \cdot 3924$

1.6359

1.5240

1.5022

1.5253

$1 \cdot 2777$

1.1918

$1 \cdot 1987$

1.5269

\section{3rd}

$2 \cdot 0545$

2.3114

2.0516

1.5896

$1 \cdot 8151$

$1 \cdot 9949$

$1 \cdot 8828$

$1 \cdot 6432$

1.6354

1.5432

1.5141

1.5624

$1 \cdot 6223$

1.5297

1.5973

$1 \cdot 6263$

$1 \cdot 5431$

1.5196
Function

Cell cycle

Unknown

Unknown

Cell development

Signal transducer

Cell development

Enzyme

Enzyme

Growth factor

Extracellular matrix protein Enzyme

Unknown

Cell communication

Signal transducer

Electron transport

Transcription factor

Cytoskeleton organization

Cell surface protein the genes that are regulated by $\mathrm{GH}$ independent of MDI-treatment during GH-mediated adipogenesis.

\section{Discussion}

Consistent with the clinical features of GHD patients, several reports have suggested a stimulatory effect of GH on adipogenesis (Morikawa et al. 1984, Nixon \& Green 1984). While GHD patients show a decreased number of adipocytes, they can form adipose tissue (Bonnet et al. 1974, Salomon et al. 1989, Bengtsson et al. 1993). These findings suggest that GH is not a major regulator, but an important modulator for adipogenesis. In this study, GH alone could not induce adipogenesis of 3T3-L1 cells. However, GH could stimulate adipogenesis when agents with adipogenic action, such as MDI, were added. These findings support the suggestion that $\mathrm{GH}$ stimulates adipogenesis by modulating the adipogenic program. In contrast to

Table 2 Down-regulated genes

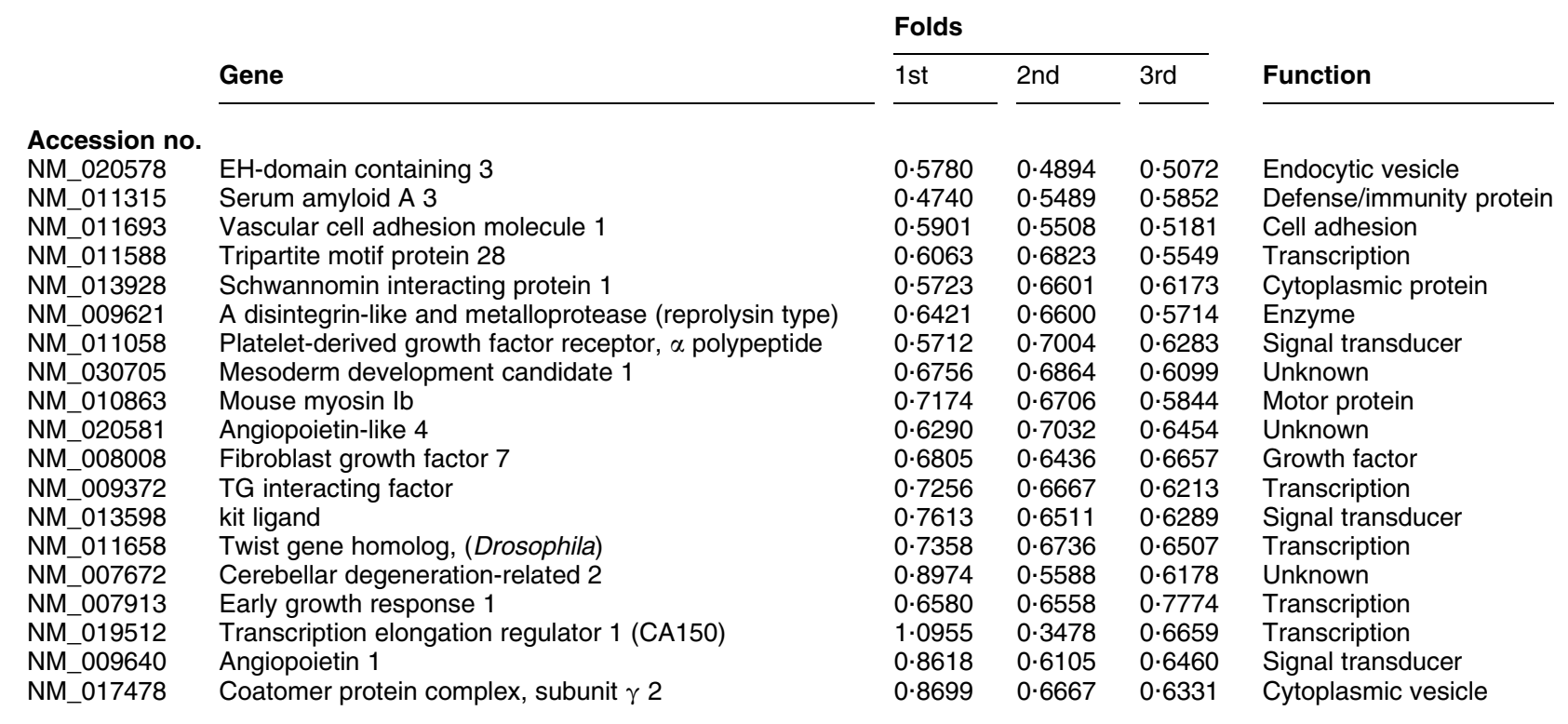




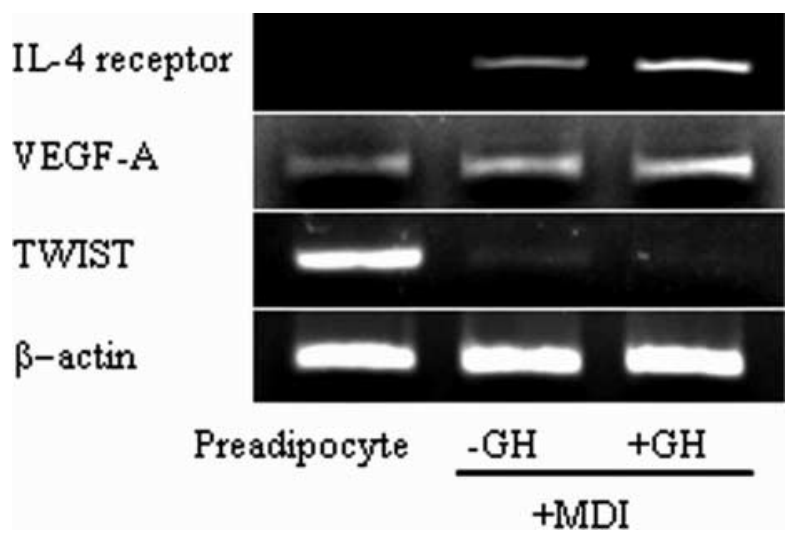

Figure 7 Semiquantitative RT-PCR analysis of IL-4 receptor, VEGF-A, and TWIST. 3T3-L1 cells were induced to differentiate with 3-h treatment of differentiation medium. Total RNA was isolated $3 \mathrm{~h}$ after adipogenic induction and cDNA was synthesized. IL-4 receptor and VEGF-A were up-regulated and TWIST was down-regulated in cells treated with $\mathrm{GH}$.

the data from cell lines, an inhibitory effect of GH on adipogenesis was reported in primary preadipocytes (Wabitsch et al. 1996, Hansen et al. 1998, Richter et al. 2003). This conflicting result of GH action may come from the different characteristics between cell lines and primary preadipocytes. Actually, it was pointed out that primary preadipocytes may have been at a later stage of adipogenesis beyond that of established preadipocyte models (Wabitsch et al. 1995, Gregoire et al. 1998, Nam \& Marcus 2000). Alternatively, treatment with GH is not required in primary cultures due to their prior in vivo exposure to circulating GH. We speculate that primary preadipocytes have already been primed with $\mathrm{GH}$ and therefore GH cannot stimulate adipogenesis in primary preadipocytes. To clarify the role of GH on adipogenesis more clearly, we think it useful to use the primary preadipocytes isolated from GHD mice (lit/lit mice).

In cells subject to our differentiation protocol, the expression of PPAR $\gamma 2$ increased earlier in cells treated with GH. Although the enhancement of $\mathrm{C} / \mathrm{EBP} \beta$ and/or $\mathrm{C} / \mathrm{EBP} \delta$ expression was thought to be a candidate to induce the early expression of PPAR $\gamma 2$, $\mathrm{GH}$ did not have any influence on the expression of $\mathrm{C} / \mathrm{EBP} \beta$ and $\mathrm{C} / \mathrm{EBP} \delta$ in $3 \mathrm{~T} 3-\mathrm{L} 1$ cells. Since we cannot exclude the possibility of involvement of $\mathrm{C} / \mathrm{EBP} \beta$ and/or C/EBP $\delta$ in GH-mediated adipogenesis in 3T3$\mathrm{L} 1$ cells, the intracellular localization of $\mathrm{C} / \mathrm{EBP} \beta$ and $\mathrm{C} / \mathrm{EBP} \delta$ during GH-mediated adipogenesis was assessed by immunofluorescence taken $1 \mathrm{~h}$ after induction. Expression of $\mathrm{C} / \mathrm{EBP} \beta$ and $\mathrm{C} / \mathrm{EBP} \delta$ was restricted in the nucleus and there was no difference between the cells treated with or without GH (data not shown). Furthermore, GH was reported to cause the rapid and transient dephosphorylation of $\mathrm{C} / \mathrm{EBP} \beta$ in 3T3-F442A cells (Liao et al. 1999, Piwien-Pilipuk et al. 2001). Therefore, we analyzed the dephosphorylation of $\mathrm{C} / \mathrm{EBP} \beta$ in response to $\mathrm{GH}$ in 3T3-L1 cells during adipogenesis. Lysates from nuclear extracts were separated with SDS-PAGE and immunoblotted with $\mathrm{C} / \mathrm{EBP} \beta$ antibody, showing no band representing the faster migrating forms of $\mathrm{C} / \mathrm{EBP} \beta$ indicated in the previous reports (Liao et al. 1999, Piwien-Pilipuk et al. 2001; data not shown). Our data, together with previous studies, demonstrated that $\mathrm{GH}$ stimulates adipogenesis of 3T3-L1 cells through the enhancement of PPAR $\gamma$ expression, not $\mathrm{C} / \mathrm{EBP} \beta / \delta$ expression (Tominaga et al. 2002). However, the mechanisms by which GH enhances PPAR $\gamma$ expression remain to be determined.

GH mediates its action through various pathways, such as Stat, mitogen activated protein kinase (MAPK), and phosphatidyl-inositol 3 kinase (PI3K) (Piwien-Pilipuk et al. 2002). Among these signaling molecules, Stat5 was reported to be involved in adipose tissue formation (Teglund et al. 1998). Therefore, we examined the effect of Stat5A/5B on GH-mediated adipogenesis. To investigate the role of Stat $5 \mathrm{~A} / 5 \mathrm{~B}$ in the adipogenic effect of $\mathrm{GH}$, Stat5A-Y694F was utilized. Overexpression of Stat5A-Y694F suppressed the stimulatory effect of GH in MDI-induced adipogenesis with the reduction of PPAR $\gamma 2$ expression, indicating that GH mediates its adipogenic effect through Stat5A/5B $\operatorname{PPAR} \gamma$. However, the stimulatory effect of GH was not completely diminished by overexpression of Stat5AY694F. This is probably because remaining endogeneous Stat5A/5B activity mediates some GH action and/or because factors other than Stat $5 \mathrm{~A} / 5 \mathrm{~B}$ may be involved in this stimulatory effect of GH. In addition, overexpression of Stat5A and 5B enhanced MDIinduced adipogenesis. Although PPAR $\gamma 2$ expression at an early stage of adipogenesis was enhanced in a GH-dependent manner, Oil Red O staining 6 days after induction showed no GH-dependent enhancement (Fig. 4C). This finding was partly explained by the Stat5 activation independent of GH over $24 \mathrm{~h}$ after adipogenic induction (Fig. 3A and $\mathrm{B}$ ). Western blot analysis in Fig. 4D and $\mathrm{E}$ was performed $9 \mathrm{~h}$ after adipogenic induction, when the cells in the absence of GH showed no nuclear translocation of Stat5. In this condition, GH significantly induced the PPAR $\gamma 2$ expression. Therefore, the up-regulation of PPAR $\gamma 2$ in the cells with $\mathrm{GH}$ could be explained by the difference of nuclear Stat5 expression. While Oil Red Staining in Fig. 4B and $\mathrm{C}$ was performed 6 days after induction, Stat5 is translocated into nucleus even in the cells without GH. GH-independent activation of Stat5, especially in the culture system where Stat5 is overexpressed, may have been enough to stimulate MDIinduced adipogenesis even in the absence of GH.

Although Stat5A is reported to be necessary for GH-dependent adipogenesis in 3T3-F442A cells (Yarwood et al. 1999, Shang \& Waters 2003), as far as we know, our study is the first report investigating the 
adipogenic effect of the GH-Stat5A signaling pathway in 3T3-L1 cells. Nanbu-Wakao et al. (2002) reported that the overexpression of Stat5A stimulates adipogenesis and Stat5A-Y694F partially suppresses adipogenesis of 3T3-L1 cells, and Stewart et al. (2004) reported that Stat5 activator can replace the requirement of FCS in 3T3-L1 adipogenesis. However, the effect of GH on adipogenesis was not demonstrated in these reports. In addition to the adipogenic effect of the GH-Stat5A signaling pathway, we also revealed the adipogenic effect of the GH-Stat5B signaling pathway. As Floyd \& Stephens (2003) reported that Stat5B cannot stimulate adipogenesis in both BALB/c and NIH-3T3 cells treated with MDI, this difference may come from the use of different cells.

Importantly, our findings also suggested the possibility that PPAR $\gamma$ mediates the adipogenic effect of the GH-Stat5A/5B signaling pathway. To elucidate the role of PPAR $\gamma$ in the adipogenic effect of the GH-Stat5A/B signaling pathway, we first investigated the relationship between Stat5A/5B and $\mathrm{C} / \mathrm{EBP} \beta / \delta$. In the present study, Stat $5 \mathrm{~A}$ and $5 \mathrm{~B}$ stimulated $\mathrm{C} / \mathrm{EBP} \beta-$ and $\mathrm{C} / \mathrm{EBP} \delta-$ induced adipogenesis with the enhancement of PPAR $\gamma$ expression. Since Stat5A and $5 \mathrm{~B}$ enhanced the transcriptional activity of $\mathrm{C} / \mathrm{EBP} \beta / \delta$ in the $P P A R \gamma$ gene promoter, this suggests that Stat5A and $5 \mathrm{~B}$ stimulate adipogenesis by inducing PPAR $\gamma$ expression in cooperation with $\mathrm{C} / \mathrm{EBP} \beta / \delta$. Next, we investigated the relationship between Stat $5 \mathrm{~A} / 5 \mathrm{~B}$ and PPAR $\gamma$. Stat $5 \mathrm{~A}$ and 5B stimulated PPAR $\gamma$-induced adipogenesis and enhanced the transcriptional activity of PPAR $\gamma$, indicating that Stat5A and 5B stimulate adipogenesis by reinforcing the transcriptional activity of PPAR $\gamma$. In contrast to our results, Stat5A and 5B have been reported to inhibit the transcriptional activity of PPAR $\gamma$ in COS1 and HEK293 cells (Richter et al. 2003, Shipley \& Waxman 2004). These results were repeatable in our hands (data not shown). These findings indicate that the effect of Stat $5 \mathrm{~A} / 5 \mathrm{~B}$ on the transcriptional activity of PPAR $\gamma$ is dependent on the cell type and Stat $5 \mathrm{~A} / 5 \mathrm{~B}$ up-regulates the transcriptional activity of PPAR $\gamma$ in cell lines with adipogenic potential, including 3T3-L1 and C3H10T1/2 cells. Taken together, the GHStat5A/5B signaling pathway stimulates adipogenesis through two distinct steps; one is transcriptional activation of $\mathrm{C} / \mathrm{EBP} \beta / \delta$ in the $P P A R \gamma$ gene promoter and the other is direct activation of PPAR $\gamma$ activity.

Although we mainly focused on the postreceptor events in this study, it is important to consider the role of GHR to completely understand the role of GH. GHR has the truncated splice variants, which inhibit fulllength GHR in a dominant-negative manner (Ross et al. 1997). In 3T3-L1 cells, full-length GHR is expressed 100 times as much as the truncated form of GHR, and expression of full-length GHR increases as adipogenesis proceeds, while the truncated form does not (Iida et al.
2003). We performed RT-PCR analysis and obtained similar findings (data not shown). Considering the abundance of full-length GHR expression and the finding that expression level of full-length GHR increases in parallel with adipogenesis, dominantnegative effect of truncated variants of GHR has minimal effect of GH-mediated adipogenesis in 3T3L1 cells. We have to consider the effect of GH-binding protein (GHBP), because expression of GHBP increases in parallel with adipogenesis (Zou et al. 1997). GHBP has been demonstrated to compete with GHR for ligand binding in the extracellular space in vitro (Lim et al. 1990); however, other aspects of GHBP function have been reported (Bick et al. 1994, Graichen et al. 2003). GHBP is also localized intracellularly, both attached to intracellular membranes and soluble in the cytoplasm and nucleoplasm (Lobie et al. 1992, Frick et al. 1994), and intracellular GHBP functions as a transcriptional enhancer in GH-stimulated Stat5-mediated transcription (Graichen et al. 2003). Therefore, we cannot exclude the possibility that GH stimulates adipogenesis partly through intracellular GHBP and further investigations are needed to clarify this.

Other genes have also been reported to be involved in the adipogenic effect of GH (Clarkson et al. 1999, Shang et al. 2002). IGF-I has been reported to stimulate adipogenesis of 3T3-L1 cells (Smith et al. 1988). As the production of IGF-I is up-regulated in response to GH in various cells (Piwien-Pilipuk et al. 2002), there arises the possibility that GH exerts its adipogenic effect through production of IGF-I. To address this, we examined IGF-I expression by semiquantitative RT-PCR analysis. IGF-I expression could not be detected in 3T3-LI preadipocytes, while it was detected in 3T3-L1 adipocytes (data not shown). When analyzed $3 \mathrm{~h}$ after adipogenic induction, IGF-1 expression was not detected in cells treated with or without GH (data not shown). These results indicate the low possibility of IGF-I involvement in the stimulatory effect of GH in the early stage of adipogenesis.

Next, we analyzed the expression of genes at an early stage using cDNA microarray analysis (Tables 1 and 2). The expression of IL-4 receptor transiently increases during the early stage of adipogenesis of 3T3-L1 cells treated with MDI, and the expression pattern of IL-4 receptor was reported to be very similar to that of C/ EBP $\beta$ (Hua et al. 2004). Our cDNA microarray analysis demonstrated that the expression of IL-4 receptor increased in cells treated with GH, suggesting the possibility that IL-4 signaling participates in the adipogenic effect of GH. Considering the expression pattern of IL-4 receptor, IL-4 signaling may be involved in clonal expansion. However, no proof of adipogenic effect of IL-4 signaling was reported (Hua et al. 2004). 
VEGF-A expression was also up-regulated in cells treated with GH. Adipose tissue mass can be regulated by its vasculature (Rupnick et al. 2002). In addition, reciprocal interaction between adipogenesis and angiogenesis is crucial in the formation of adipose tissue, and VEGF-A was reported to be involved in this interaction (Fukumura et al. 2003). VEGF-A is expressed in adipocytes but not in preadipocytes both in vitro and in vivo (Soukas et al. 2001). As GH is important in the regulation of angiogenesis, it may induce adipogenesis through the promotion of angiogenesis. Other than VEGF-A, the expression levels of growth factors and their receptors were altered in response to GH. Although their contribution to adipogenesis was unclear, these results suggest that GH stimulates adipogenesis in association with cell growth modulation. In addition to growth factors, the expression of TWIST, a basic helix-loop-helix transcription factor, was down-regulated. The down-regulation of TWIST may have an impact on adipogenesis because TWIST is involved in osteogenesis and chondrogenesis (Bialek et al. 2004, Reinhold et al. 2006), and adipocytes, osteoblasts, and chondrocytes originate from the same precursor stem cells, mesenchymal stem cells.

In summary, our data demonstrate that GH stimulates adipogenesis under adipogenic induction through the enhancement of PPAR $\gamma$ expression, and both Stat5A and 5B are involved in the adipogenic effect of $\mathrm{GH}$. In addition, we provide evidence that Stat5A and $5 \mathrm{~B}$ function in association with $\mathrm{C} / \mathrm{EBP} \beta, \mathrm{C} / \mathrm{EBP} \delta$, and $\operatorname{PPAR} \gamma$ resulting in the promotion of adipogenesis.

\section{Acknowledgements}

The authors thank Dr Hiroko Yamashita (Nagoya City University Graduate School of Medical Sciences, Nagoya, Japan) for Stat5 expression vector and pZZ1 vector, and Dr John J Kopchick (Ohio University, Ohio) for $\mathrm{GH}$ receptor expression vector. M Kawai declares that there is no conflict of interest that would prejudice the impartiality of this scientific work.

\section{References}

Bengtsson BA, Eden S, Lonn L, Kvist H, Stokland A, Lindstedt G, Bosaeus I, Tolli J, Sjostrom L \& Isaksson OG 1993 Treatment of adults with growth hormone $(\mathrm{GH})$ deficiency with recombinant human GH. Journal of Clinical Endocrinology and Metabolism 76 309-317.

Bialek P, Kern B, Yang X, Schrock M, Sosic D, Hong N, Wu H, Yu K, Ornitz DM, Olspn EN et al. 2004 A twist code determines the onset of osteoblast differentiation. Developmental Cell 6 423-435.

Bick T, Frick GP, Leonard D, Leonard JL \& Goodman HM 1994 Overexpression of the short form of the growth hormone receptor in 3T3-L1 mouse preadipocytes. Proceedings of the Society for Experimental Biology and Medicine 206 185-189.
Bonnet F, Vanderschueren-Lodeweyckx M, Eeckels R \& Malvaux P 1974 Subcutaneous adipose tissue and lipids in blood in growth hormone deficiency before and after treatment with human growth hormone. Pediatric Research 8 800-805.

Clarkson RW, Chen CM, Harrison S, Wells C, Muscat GE \& Waters MJ 1995 Early responses of trans-activating factors to growth hormone in preadipocytes: differential regulation of CCAAT enhancerbinding protein-beta (C/EBP beta) and C/EBP delta. Molecular Endocrinology 9 108-120.

Clarkson RW, Shang CA, Levitt LK, Howard T \& Waters MJ 1999 Ternary complex factors Elk-1 and Sap-la mediate growth hormone-induced transcription of egr-1 (early growth response factor-1) in 3T3-F442A preadipocytes. Molecular Endocrinology 13 619-631.

Corin RE, Guller S, Wu KY \& Sonenberg M 1990 Growth hormone and adipose differentiation: growth hormone-induced antimitogenic state in 3T3-F442A preadipose cells. PNAS 87 7507-7511.

Darnell JE Jr 1997 STATs and gene regulation. Science 277 1630-1635.

Doglio A, Dani C, Grimaldi P \& Ailhaud G 1986 Growth hormone regulation of the expression of differentiation-dependent genes in preadipocyte Ob1771 cells. Biochemical Journal 238 123-129.

Floyd ZE \& Stephens JM 2003 STAT5A promotes adipogenesis in nonprecursor cells and associates with the glucocorticoid receptor during adipocyte differentiation. Diabetes 52 308-314.

Frick GP, Tai LR \& Goodman HM 1994 Subcellular distribution of the long and short isoforms of the growth hormone $(\mathrm{GH})$ receptor in rat adipocytes: both isoforms participate in specific binding of $\mathrm{GH}$. Endocrinology 134 307-314.

Fukumura D, Ushiyama A, Duda DG, Xu L, Tam J, Krishna V, Chatterjee K, Garkavtsev I \& Jain RK 2003 Paracrine regulation of angiogenesis and adipocyte differentiation during in vivo adipogenesis. Circulation Research 93 e88-e97.

Graichen R, Sandstedt J, Goh EL, Isaksson OG \& Lobie PE 2003 The growth hormone-binding protein is a location-dependent cytokine receptor transcriptional enhancer. Journal of Biological Chemistry $\mathbf{2 7 8}$ $6346-6354$.

Gregoire FM, Smas CM \& Sul HS 1998 Understanding adipocyte differentiation. Physiological Reviews 78 783-809.

Guller S, Sonenberg M, Wu KY, Szabo P \& Corin RE 1989 Growth hormone-dependent events in the adipose differentiation of 3T3F442A fibroblasts: modulation of macromolecular synthesis. Endocrinology 125 2360-2367.

Gurland G, Ashcom G, Cochran BH \& Schwartz J 1990 Rapid events in growth hormone action. Induction of c-fos and c-jun transcription in 3T3-F442A preadipocytes. Endocrinology 127 3187-3195.

Hansen LH, Madsen B, Teisner B, Nielsen JH \& Billestrup N 1998 Characterization of the inhibitory effect of growth hormone on primary preadipocyte differentiation. Molecular Endocrinology 12 $1140-1149$.

Hua K, Deng J \& Harp JB 2004 Interleukin-4 inhibits platelet-derived growth factor-induced preadipocyte proliferation. Cytokine $\mathbf{2 5}$ $61-67$.

Huo JS, McEachin RC, Cui TX, Duggal NK, Hai T, States DJ \& Schwartz J 2006 Profiles of growth hormone $(\mathrm{GH})$-regulated genes reveal timedependent responses and identify a mechanism for regulation of activating transcription factor 3 by GH. Journal of Biological Chemistry $2814132-4141$.

Ichida F, Nishimura R, Hata K, Matsubara T, Ikeda F, Hisada K, Yatani H, Cao X, Komori T \& Yamaguchi A 2004 Reciprocal roles of Msx2 in regulation of osteoblast and adipocyte differentiation. Journal of Biological Chemistry 279 34015-34022.

Iida K, Takahashi Y, Kaji H, Yoshioka S, Murata M, Iguchi G, Okimura Y \& Chihara K 2003 Diverse regulation of full-length and truncated growth hormone receptor expression in 3T3-L1 adipocytes. Molecular and Cellular Endocrinology 210 21-29.

Isaksson OG, Jansson JO \& Gause IA 1982 Growth hormone stimulates longitudinal bone growth directly. Science 216 1237-1239. 
Kliewer SA, Forman BM, Blumberg B, Ong ES, Borgmeyer U, Mangelsdorf DJ, Umesono K \& Evans RM 1994 Differential expression and activation of a family of murine peroxisome proliferator-activated recetpors. PNAS 91 7355-7359.

Liao J, Piwien-Pilipuk G, Ross SE, Hodge CL, Sealy L, MacDougald OA \& Schwartz J 1999 CCAAT/enhancer-binding protein beta (C/EBPbeta) and C/EBPdelta contribute to growth hormoneregulated transcription of c-fos. Journal of Biological Chemistry 274 31597-31604.

Lim L, Spencer SA, McKay P \& Waters MJ 1990 Regulation of growth hormone $(\mathrm{GH})$ bioactivity by a recombinant human GH-binding protein. Endocrinology 127 1287-1291.

Lobie PE, Garcia-aragon J, Wang BS, Baumbach WR \& Waters MJ 1992 Cellular localization of the growth hormone binding protein in the rat. Endocrinology 130 3057-3065.

Morikawa M, Green H \& Lewis UJ 1984 Activity of human growth hormone and related polypeptides on the adipose conversion of 3T3 cells. Molecular and Cellular Biology 4 228-231.

Nam SY \& Lobie PE 2000 The mechanism of effect of growth hormone on preadipocyte and adipocyte function. Obesity Reviews 1 73-86.

Nam SY \& Marcus C 2000 Growth hormone and adipocyte function in obesity. Hormone Research 53 87-97.

Nanbu-Wakao R, Morikawa Y, Matsumura I, Masuho Y, Muramatsu MA, Senba E \& Wakao H 2002 Stimulation of 3T3-L1 adipogenesis by signal transducer and activator of transcription 5. Molecular Endocrinology 16 1565-1576.

Nixon T \& Green H 1984 Contribution of growth hormone to the adipogenic activity of serum. Endocrinology 114 527-532.

Orlicky DJ \& Schaack J 2001 Adenovirus transduction of 3T3-L1 cells. Journal of Lipid Research 42 460-466.

Piwien-Pilipuk G, Van Mater D, Ross SE, MacDougald OA \& Schwartz J 2001 Growth hormone regulates phosphorylation and function of CCAAT/enhancer-binding protein beta by modulating Akt and glycogen synthase kinase-3. Journal of Biological Chemistry 276 19664-19671.

Piwien-Pilipuk G, Huo JS \& Schwartz J 2002 Growth hormone signal transduction. Journal of Pediatric Endocrinology and Metabolism 15 $771-786$.

Reinhold MI, Kapadia RM, Liao Z \& Naski MC 2006 The Wntinducible transcription factor Twist1 inhibits chondrogenesis. Journal of Biological Chemistry 281 1381-1388.

Richter HE, Albrektsen T \& Billestrup N 2003 The role of signal transducer and activator of transcription 5 in the inhibitory effects of GH on adipocyte differentiation. Journal of Molecular Endocrinology 30 139-150.

Rosen ED \& Spiegelman BM 2000 Molecular regulation of adipogenesis. Annual Review of Cell and Developmental Biology 16 145-171.

Rosen ED, Sarraf P, Troy AE, Bradwin G, Moore K, Milstone DS, Spiegelman BM \& Mortensen RP 1999 PPAR gamma is required for the differentiation of adipose tissue in vivo and in vitro. Molecular Cell 4 611-617.

Ross RJ, Esposito N, Shen XY, Von Laue S, Chew SL, Dobson PR, Postel-Vinay MC \& Finidori J 1997 A short isoform of the human growth hormone receptor functions as a dominant negative inhibitor of the full-length receptor and generates large amounts of binding protein. Molecular Endocrinology 11 265-273.

Rowland JE, Lichanska AM, Kerr LM, White M, d'Aniello EM, Maher SL, Brown R, Teasdale RD, Noakes PG \& Waters MJ 2005 In vivo analysis of growth hormone receptor signaling domains and their associated transcripts. Molecular and Cellular Biology 25 66-77.

Rubin CS, Hirsch A, Fung C \& Rosen OM 1978 Development of hormone receptors and hormonal responsiveness in vitro. Insulin receptors and insulin sensitivity in the preadipocyte and adipocyte forms of 3T3-L1 cells. Journal of Biological Chemistry 253 7570-7578.

Ruff-Jamison S, Chen K \& Cohen S 1995 Epidermal growth factor induces the tyrosine phosphorylation and nuclear translocation of Stat 5 in mouse liver. PNAS 92 4215-4218.
Rupnick MA, Panigrahy D, Zhang CY, Dallabrida SM, Lowell BB, Langer R \& Folkman MJ 2002 Adipose tissue mass can be regulated through the vasculature. PNAS 99 10730-10735.

Salomon F, Cuneo RC, Hesp R \& Sonksen PH 1989 The effects of treatment with recombinant human growth hormone on body composition and metabolism in adults with growth hormone deficiency. New England Journal of Medicine 321 1797-1803.

Shang CA \& Waters MJ 2003 Constitutively active signal transducer and activator of transcription 5 can replace the requirement for growth hormone in adipogenesis of 3T3-F442A preadipocytes. Molecular Endocrinology 17 2494-2508.

Shang CA, Thompson BJ, Teasdale R, Brown RJ \& Waters MJ 2002 Genes induced by growth hormone in a model of adipogenic differentiation. Molecular and Cellular Endocrinology 189 213-219.

Shipley JM \& Waxman DJ 2004 Simultaneous, bidirectional inhibitory crosstalk between PPAR and STAT5b. Toxicology and Applied Pharmacology 199 275-284.

Smith PJ, Wise LS, Berkowitz R, Wan C \& Rubin CS 1988 Insulin-like growth factor-I is an essential regulator of the differentiation of 3T3L1 adipocytes. Journal of Biological Chemistry 263 9402-9408.

Soukas A, Socci ND, Saatkamp BD, Novelli S \& Friedman JM 2001 Distinct transcriptional profiles of adipogenesis in vivo and in vitro. Journal of Biological Chemistry 276 34167-34174.

Stewart WC, Baugh JE Jr, Floyd ZE \& Stephens JM 2004 STAT 5 activators can replace the requirement of FBS in the adipogenesis of 3T3-L1 cells. Biochemical and Biophysical Research Communications 324 355-359.

Tanaka T, Yoshida N, Kishimoto T \& Akira S 1997 Defective adipocyte differentiation in mice lacking the C/EBPbeta and/or C/EBPdelta gene. EMBO Journal 16 7432-7443.

Teglund S, McKay C, Schuetz E, van Deursen JM, Stravopodis D, Wang D, Brown M, Bodner S, Grosveld G \& Ihle JN 1998 Stat5a and Stat5b proteins have essential and nonessential, or redundant, roles in cytokine responses. Cell 93 841-850.

Tollet-Egnell P, Parini P, Stahlberg N, Lonnstedt I, Lee NH, Rudling M, Flores-Morales A \& Norstedt G 2004 Growth hormone-mediated alteration of fuel metabolism in the aged rat as determined from transcript profiles. Physiological Genomics 16 261-267.

Tominaga S, Morikawa M \& Osumi T 2002 Growth hormone has dual stage-specific effects on the differentiation of 3T3-L1 preadipocytes. Journal of Biochemistry (Tokyo) 132 881-889.

Vidal-Puig AJ, Considine RV, Jimenez-Linan M, Werman A, Pories WJ, Caro JF \& Flier JS 1997 Peroxisome proliferator-activated receptor gene expression in human tissues. Effects of obesity, weight loss, and regulation by insulin and glucocorticoids. Journal of Clinical Investigation 99 2416-2422.

Wabitsch M, Heinze E, Hauner H \& Teller WM 1995 The role of growth hormone/insulin-like growth factors in adipocyte differentiation. Metabolism 44 45-49.

Wabitsch M, Hauner H, Heinze E, Shymko RM, Teller WM, De Meyts P \& Ilondo MM 1996 Biological effects of human growth hormone in rat adipocyte precursor cells and newly differentiated adipocytes in primary culture. Metabolism 45 34-42.

Yamashita H, Iwase H, Toyama T \& Fujii Y 2003 Naturally occurring dominant-negative Stat5 suppresses transcriptional activity of estrogen receptors and induces apoptosis in T47D breast cancer cells. Oncogene 22 1638-1652.

Yarwood SJ, Sale EM, Sale GJ, Houslay MD, Kilgour E \& Anderson NG 1999 Growth hormone-dependent differentiation of 3T3-F442A preadipocytes requires Janus kinase/signal transducer and activator of transcription but not mitogen-activated protein kinase or p70 S6 kinase signaling. Journal of Biological Chemistry 274 8662-8668.

Zou L, Menon RK \& Sperling MA 1997 Induction of mRNAs for the growth hormone receptor gene during mouse 3T3-L1 preadipocyte differentiation. Metabolism 46 114-118.

Received 12 September 2006

Accepted 11 October 2006 